\title{
EVALUATION OF STRATIGRAPHIC CONTINUITY BETWEEN THE FORTRESS MOUNTAIN AND NANUSHUK FORMATIONS IN THE CENTRAL BROOKS RANGE FOOTHILLS_ARE THEY PARTLY CORRELATIVE?
}

\author{
by
}

Marwan A. Wartes ${ }^{1}$

\section{INTRODUCTION}

The Colville Basin in northern Alaska is a large east-trending foreland basin that developed north of the Brooks Range fold and thrust belt in the Early Cretaceous (Mull, 1985; Bird and Molenaar, 1992; figs. 1-2). The southern margin of the basin is generally regarded as gas-prone, although it remains underexplored relative to the rest of the North Slope (Houseknecht and Bird, 2006). Seismic data are poor throughout this belt (Molenaar, 1988), leading to uncertainty regarding regional stratigraphic relationships.

The purpose of this paper is to examine the poorly understood stratigraphic relationship between the Fortress Mountain and Nanushuk ${ }^{2}$ Formations - two of the most prospective siliciclastic units exposed in the inner foothills. Many previous workers have interpreted the two units as discrete depositional cycles, often separated by a "tongue" of mudstone-dominated Torok Formation (Mull, 1985; Moore and others, 1994; fig. 3). However, in the field the relationship between the two formations is unclear and the two distinct belts of resistant exposures are never observed in close spatial association (fig. 2). To date, it has been difficult to prove the two units did not overlap in time, leading some workers to entertain the hypothesis that the uppermost Fortress Mountain Formation graded northward into the lower Nanushuk Formation (Kelley, 1990). In addition to ambiguous field relationships, available biostratigraphic constraints have largely proven insufficient to address this question. This study takes an alternate approach, testing the stratigraphic continuity of the two units on the basis of their provenance characteristics - specifically, the novel application of detrital zircon geochronology. Preliminary results strongly suggest the two units represent different depositional sequences.

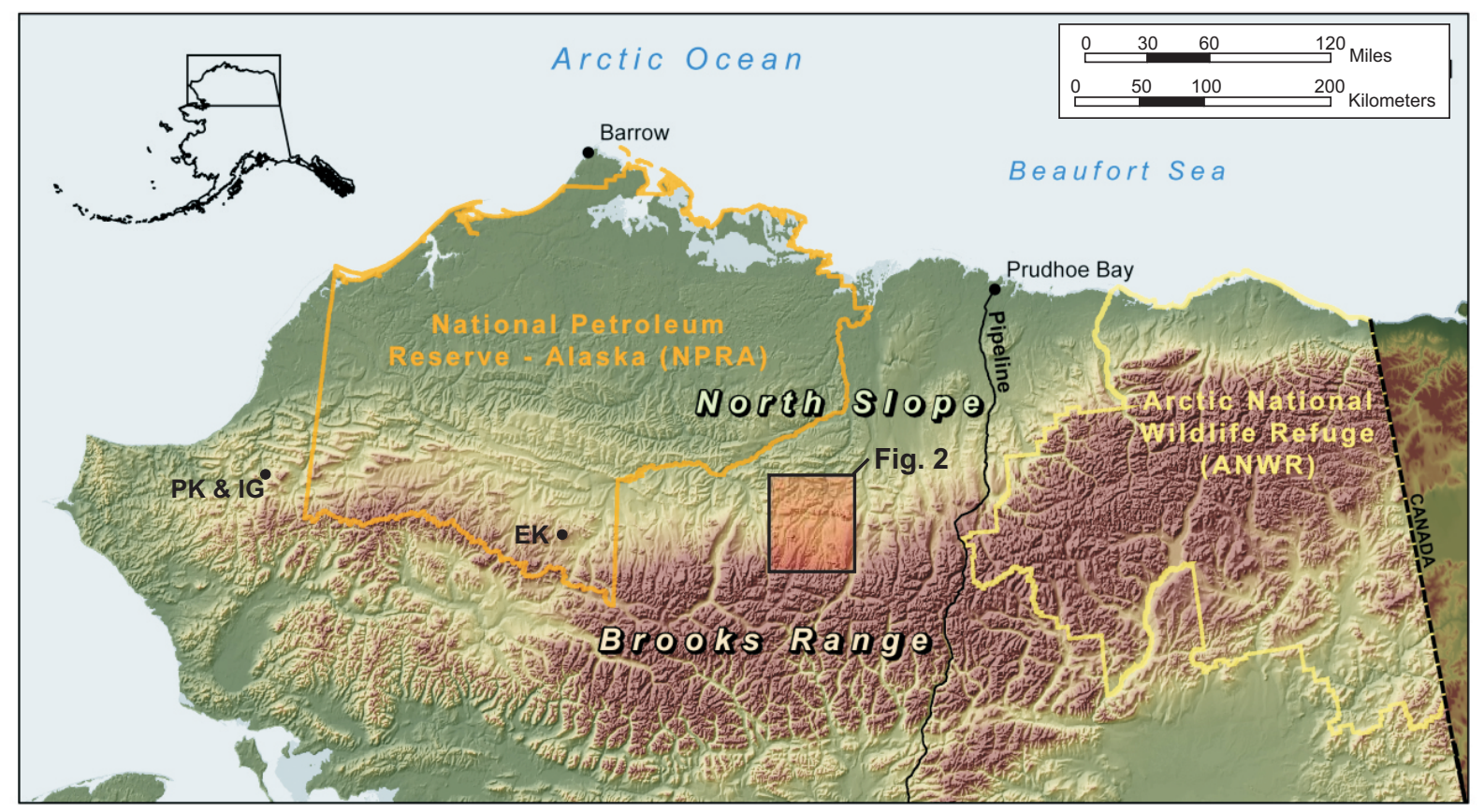

Figure 1. Regional location map of northern Alaska. Initials refer to localities outside of the study area that are mentioned in the text (PK \& IG = Poko Mountain and Igloo Mountain; EK = Ekakevik Mountain).

\footnotetext{
${ }^{1}$ Alaska Division of Geological \& Geophysical Surveys, 3354 College Rd., Fairbanks, Alaska 99709-3707 Email for Marwan A. Wartes: marwan.wartes@alaska.gov

${ }^{2}$ The Nanushuk has historically been ascribed Group status (Detterman, 1956). However, in a comprehensive revision and simplification of Brookian stratigraphic nomenclature, Mull and others (2003) suggested the Nanushuk be demoted to formation rank.
} 


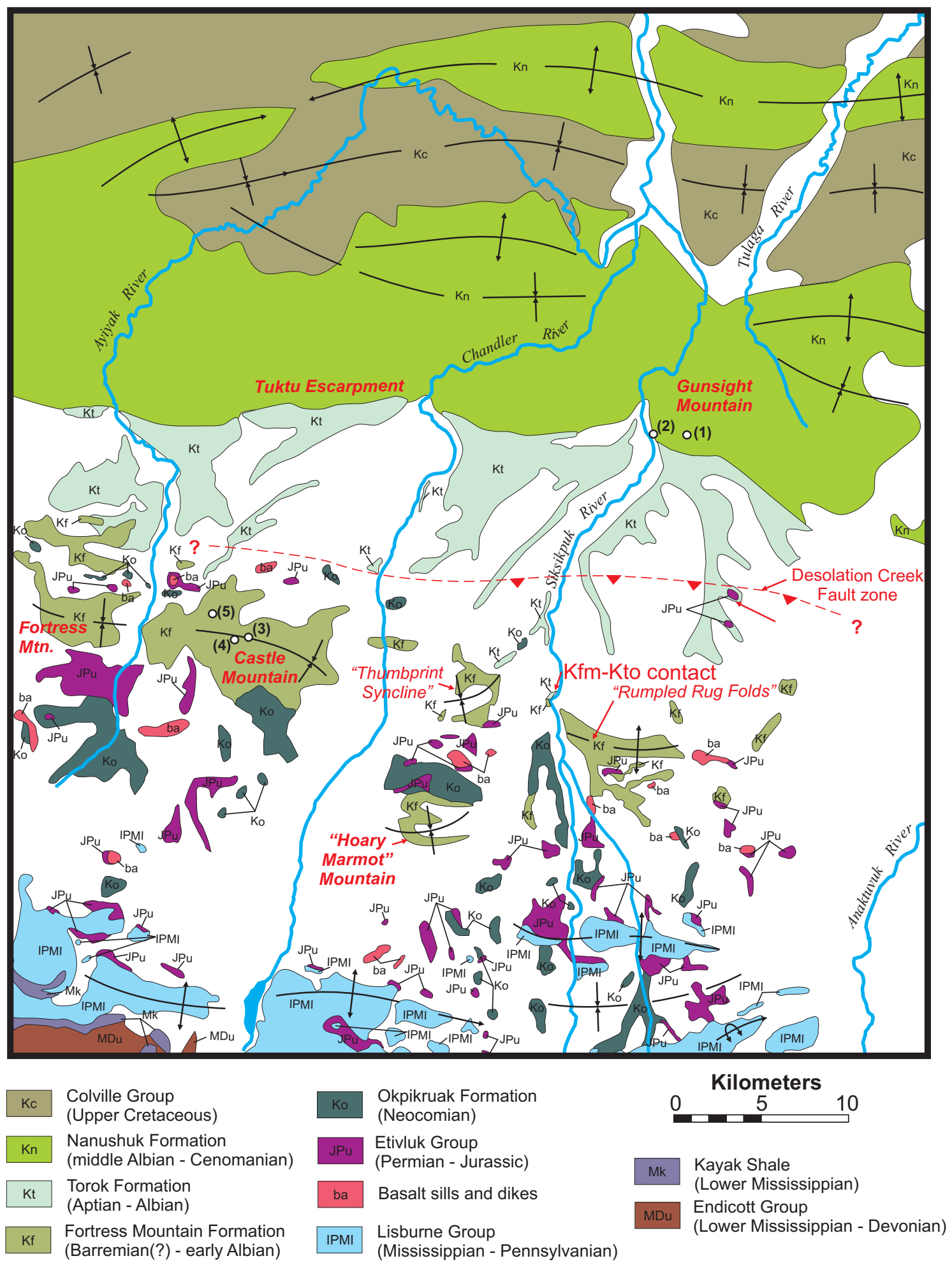

Figure 2. Generalized geologic map of the east-central foothills (modified slightly from C.G. Mull, unpublished mapping). Numbered locations refer to samples in this study (see table 1). 


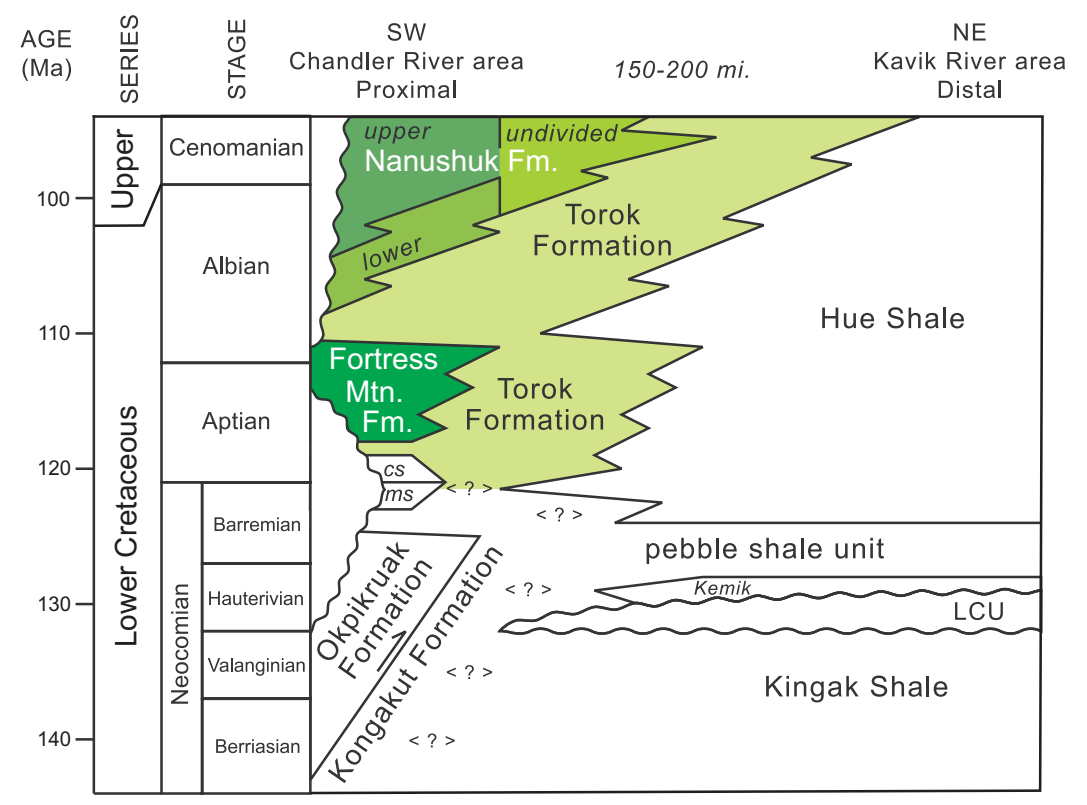

Figure 3. Chronostratigraphy of middle Cretaceous units in northern Alaska showing revised stratigraphic nomenclature (modified from Mull and others, 2003). $c s=c o b$ blestone sandstone (informal unit); ms = manganiferous shale unit (informal).

\section{EXISTING CONSTRAINTS}

\section{Map relationships}

Early reconnaissance mapping recognized that at a regional scale progressively younger Brookian units typically crop out from south to north (Patton and Tailleur, 1964). This general observation supports the interpretation that the southerly belt of Fortress Mountain Formation is older than the more northerly Nanushuk Formation trend. However, the top of the Fortress Mountain Formation is almost never exposed. Moreover, the two units are never observed together, but are instead separated by a poorly exposed, low-relief succession of finer-grained Torok Formation (figs. 2 and 4). The broad zone of Torok Formation exhibits locally complex deformation with variable fold vergence (Peapples and others, 2007). The northerly part of the Torok belt is generally interpreted as a structurally thickened triangle zone beneath a south-vergent roof thrust near the base of the Nanushuk Formation (Moore and others, 2004; Wallace and others, 2006). The uplift and subsequent erosion of post-Torok rocks has obscured the relationship between the Fortress Mountain Formation and proximal reaches of the Nanushuk Formation (fig. 4).

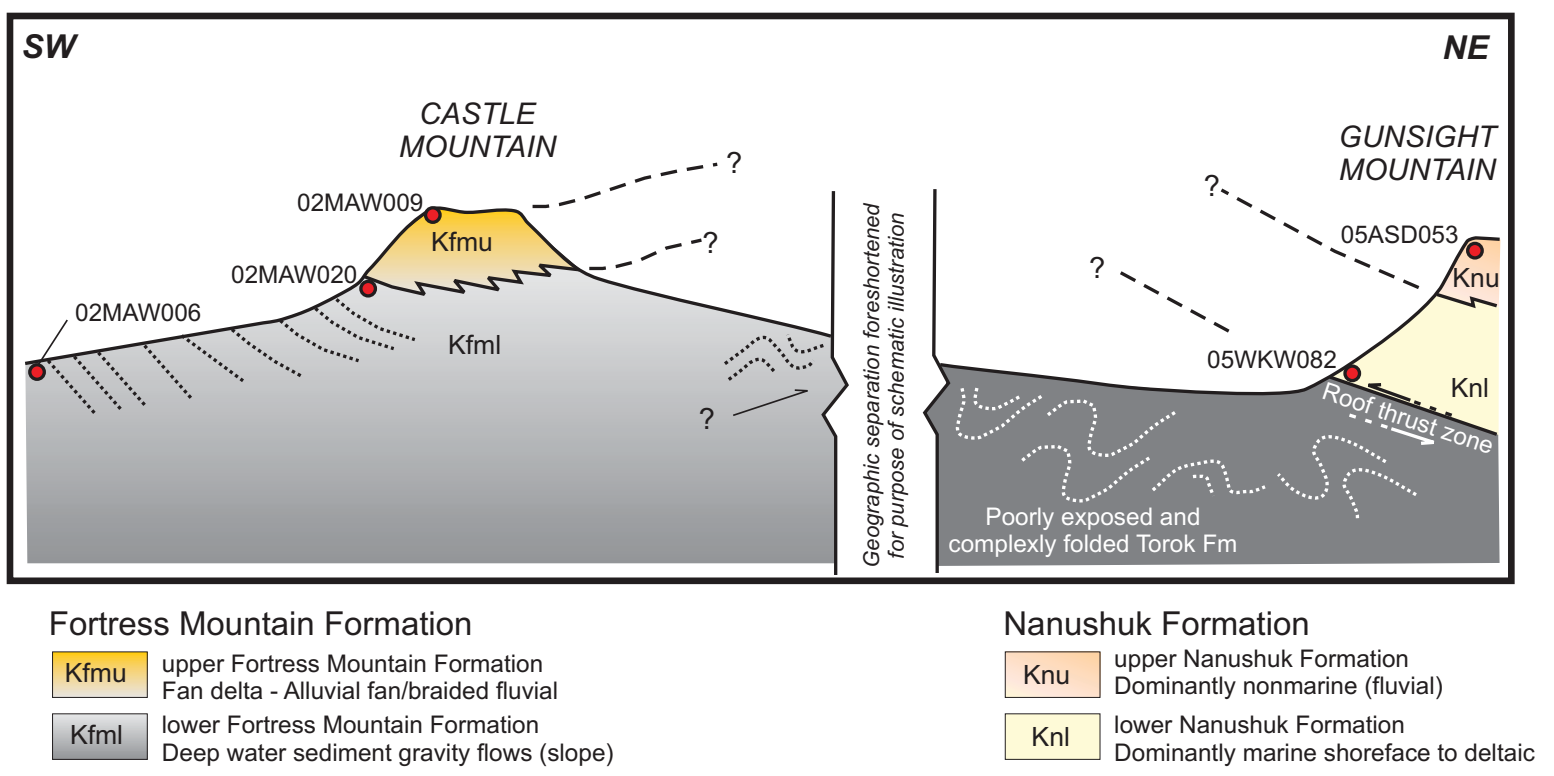

Figure 4. Schematic cross section illustrating the geography of the Fortress Mountain and Nanushuk trends and the stratigraphic uncertainty of their relationship. Note the relative location of samples in this study. 


\section{Stratigraphic Relationships}

The Fortress Mountain Formation includes a variety of facies ranging from deep marine basin floor up through alluvial fan environments (Wartes, 2008, this volume; Houseknecht and others, 2007; Crowder, 1989; Molenaar and others, 1988; Hunter and Fox, 1976). The type section of the Fortress Mountain Formation consists of a series of discontinuous exposures in the Castle Mountain area (fig. 2; Patton and Tailleur, 1964). This 3,000-m-thick section is considerably thicker than any other known outcrop of the formation and is interpreted to grade from basin floor(?) to slope facies up through fan delta, alluvial fan, and braided fluvial facies (Molenaar and others, 1988; Crowder, 1987).

The Nanushuk Formation records deposition in marine shelf, deltaic, and fluvial environments (Ahlbrandt, 1979; Huffman, 1985; LePain and others, 2008). Seismic data clearly indicate that Nanushuk topsets transition basinward (to the northeast) into clinoforms of the Torok Formation (Molenaar, 1988; Houseknecht and Schenk, 2001). In the east-central foothills, where the samples for this study were collected, the Nanushuk is approximately 1,600 m thick (Patton and Tailleur, 1964) and is subdivided into a marine lower part and a dominantly nonmarine upper part (fig. 3; Mull and others, 2003).

Regionally, the Fortress Mountain formation rapidly fines northward and locally grades into rocks assigned to the lower Torok Formation (Patton and Tailleur, 1964; Molenaar and others, 1988; fig. 3). However, at Castle Mountain the upper $350 \mathrm{~m}$ of section includes the most proximal nonmarine facies interpreted as alluvial fan and braided fluvial. The northerly equivalent of this nonmarine succession is not known and it remains possible that it graded northward into the marine facies of the lower Nanushuk. The uncertain relationship between the two units is schematically illustrated in figure 4 .

\section{Sandstone Composition}

In hand sample, sandstones of the Nanushuk Formation are often lighter colored and appear less lithic rich than darker greenish-gray-weathering Fortress Mountain Formation sandstones. This qualitative observation is borne out by regional petrographic data that indicate that Nanushuk samples from the central and eastern foothills average about 58 percent total quartz (Bartsch-Winkler and Huffman, 1988), whereas Fortress Mountain samples average only 32 percent quartz in the east-central outcrop belt (Molenaar and others, 1988). An additional notable difference documented in these studies is captured in the metamorphic lithics, which average 15 percent for the Nanushuk samples as compared to only 1 percent for Fortress Mountain samples. This stark difference was also noted by Johnsson and Sokol (2000), who documented as much as 30 percent metamorphic lithic fragments in the easternmost exposures of the Nanushuk Formation.

\section{Biostratigraphy}

The Fortress Mountain Formation is generally ascribed an Aptian(?) to early Albian age, whereas the Nanushuk Formation is regarded as middle Albian to Cenomanian (fig. 3). These assignments largely reflect detailed megafossil work done by the USGS in the 1950s and 1960s, most notably Imlay (1961). The shallow marine Nanushuk Formation has generally yielded a more diverse fauna and the biostratigraphic range can be considered more robust than the Fortress Mountain Formation. The majority of the biostratigraphic control for the Fortress Mountain Formation came from the lower third of the unit (Patton and Tailleur, 1964), leaving the upper limit of the formation in question.

Bivalves identified as similar to Inoceramus anglicus and Inoceramus altifluminis were reported from both the Fortress Mountain and Nanushuk Formations by Imlay (1961). In Alberta and British Columbia, these species were generally regarded as no older than middle Albian (McLearn, 1945). On the basis of the entire fossil assemblage from the Fortress Mountain Formation, particularly ammonite specimens, Imlay (1961) favored an interpretation that these Inoceramids must have ranged down into the early Albian in northern Alaska. More recently, Kelley (1990) reported additional specimens of I. anglicus from the Fortress Mountain Formation at Hoary Marmot Mountain (informal name; fig. 2). He interpreted an age no older than middle Albian and concluded the exposure was likely coeval with the lower part of the Nanushuk Formation.

Palynological and foraminiferal data generally offer limited biostratigraphic resolution for any of the Fortress, Nanushuk, or Torok Formations, and typically yield a significant number of “Aptian-Albian” or “Lower Cretaceous undifferentiated” age assignments (unpublished DGGS micropaleontology reports). However, there is a general observation that can be gleaned from the subset of samples that do preserve abundant age-diagnostic microfossils: the Fortress Mountain Formation samples do not appear to produce ages younger than Aptian to early Albian and the Nanushuk Formation in the central foothills does not yield ages older than middle to late Albian (written commun., M. Mickey, 2006; LePain and others, 2008). 


\section{NEW DATA}

As outlined in the preceding sections, existing constraints have proven inadequate to definitively assess the stratigraphic relationship between the Fortress Mountain and Nanushuk Formations. The following new data attempts to address the question by focusing on the provenance of the two units, specifically the U-Pb ages of detrital zircons.

\section{Detrital Zircon Geochronology}

Zircon is a common heavy mineral in most siliciclastic systems and is highly resistant to weathering and diagenesis (Fedo and others, 2003). Recent advances in analytical technology have allowed for the rapid acquisition of a large number of U-Pb ages from individual detrital zircons (Gehrels and others, 2006). The addition of this geochronologic component is revolutionizing studies of sedimentary provenance, particularly regional paleogeographic and tectonic studies (Gillis and others, 2005; Dickinson and Gehrels, 2003).

\section{Sample Selection and Methods}

In order to assess the population of detrital zircon ages from each formation, samples were selected from some of the thicker, more continuous exposures in the foothills. In the case of the Fortress Mountain Formation, three samples were selected from the type section at Castle Mountain, one from the lower and two from the upper part of the formation (figs. 2 and 4; table 1). This section is particularly appropriate as it likely contains the stratigraphically highest Fortress Mountain Formation exposed anywhere in the foothills. Two Nanushuk Formation samples were analyzed from well-exposed bluffs where the Siksikpuk River cuts across the Tuktu escarpment area; one sample is from the very base of the formation, the other from upper Nanushuk on Gunsight Mountain (figs. 2 and 4; table 1).

Zircons were separated at the Apatite-to-Zircon, Inc. laboratory using heavy liquid and magnetic separation techniques. Grains were mounted in epoxy and polished to expose grain interiors for analysis. One-hundred grains were selected at random and dated for each sample, a number commonly sought by most workers and one that reduces the probability of missing any given provenance components to < 5 percent (Dodson and others, 1988). Uranium, thorium, and lead isotope data were collected at the Washington State University Geoanalytical Laboratory on a ThermoFinnigan Element2 magnetic sector double-focusing ICP-MS (inductively coupled plasma-mass spectrometer). Each grain underwent laser ablation using a New Wave Research UP-213 system. See Chang and others (2006) for additional details regarding laboratory procedures such as standards and error corrections.

Table 1. Sample location information; note map number that refers to sample notation in figure 4.

\begin{tabular}{|c|c|c|c|}
\hline \multirow[b]{2}{*}{$\begin{array}{l}\text { Sample } \\
\text { Number }\end{array}$} & \multicolumn{3}{|c|}{ LOCATION } \\
\hline & Map \# & Description & Latitude / Longitude \\
\hline 05ASD053 & (1) & $\begin{array}{l}\text { Gunsight Mountain } \\
\text { Top of Nanushuk Fm. }\end{array}$ & N 68.71775 W 151.83504 \\
\hline 05WKW082 & $(2)$ & $\begin{array}{l}\text { Siksikpuk River } \\
\text { Base of Nanushuk Fm. }\end{array}$ & N 68.72206 W 151.88918 \\
\hline 02MAW009 & (3) & $\begin{array}{l}\text { Castle Mountain summit } \\
\text { Top of Fortress Mountain Fm. }\end{array}$ & N 68.56649 W 152.58198 \\
\hline 02MAW020 & (4) & $\begin{array}{l}\text { Castle Mountain base } \\
\text { upper Fortress Mountain Fm. }\end{array}$ & N 68.56365 W 152.60785 \\
\hline
\end{tabular}




\section{Detrital zircon populations}

Appendix C-1 includes isotopic ratio and age data for 500 individual U-Pb zircon analyses. Only one grain from sample 02MAW020 produced strongly discordant data and was rejected. For ages up to $1000 \mathrm{Ma}$, the ${ }^{206} \mathrm{~Pb} /{ }^{238} \mathrm{U}$ age is selected as the most precise; those greater than $1000 \mathrm{Ma}$ are taken from the ${ }^{206} \mathrm{~Pb} /{ }^{207} \mathrm{~Pb}$ ages (see Gehrels and others, 2006). The age distribution data for each of the five samples are plotted in a histogram format and cumulative probability curves (figs. 5-9). Histograms illustrate the number of ages that fall into each 50 Ma bin. Cumulative probability curves, which are a common method for displaying detrital zircon data, represent the normalized sum of probability distributions for all analyses from a sample. Age peaks are only considered statistically significant if defined by several analyses. All plots were created using Isoplot/Ex v. 3.32 (Ludwig, 2005).

\section{DISCUSSION}

The detrital zircon data reveal statistically significant differences between the two formations. This is best illustrated by comparing selected groups of grain ages (table 2, figs. 10 and 11). All three Fortress Mountain Formation samples include abundant Permian grains (10-19 percent), whereas the Nanushuk samples yielded only one Permian grain between both samples. Typically the parent lithology of individual zircons is difficult to assess. However, in the case of the Permian age spike, U-Pb zircon ages from igneous clasts within the Fortress Mountain Formation (Wartes and others, 2006) indicate the detrital population observed in this study was derived from an unknown tonalitic-dacitic igneous complex.

Late Neoproterozoic to Cambrian ages (500-665 Ma) form a prominent peak in both Nanushuk samples (average 23 percent) but are much less abundant, on average, in the Fortress Mountain samples (7 percent). Nanushuk samples also contain a discrete pulse of early Neoproterozoic ages (850-950 Ma) that is much less common in the Fortress Mountain samples. Similarly, Mesoproterozoic ages ( 1000-1300 Ma) form prominent peaks in both Nanushuk samples (average 20 percent), while the Fortress Mountain samples include a very weak record of this provenance (average 5 percent). Finally, although the Nanushuk Formation samples contain significantly larger proportion of Precambrian grains, the Fortress Mountain samples average almost three times more early Proterozoic grain ages (Orosirian period 1800-2050 Ma).

If the Fortress Mountain and Nanushuk Formations were in part correlative, it seems probable that the uppermost Fortress Mountain sample (02MAW009) would have been most similar to the basal Nanushuk sample (05WKW082). In fact, these two samples produced some of the starkest contrasts in several groupings of detrital grain ages (table 2; figs. 10 and 11). The two formations clearly have a different provenance for zircons and the

Table 2. Comparison of significant detrital-age groupings highlighting noteworthy differences between the Nanushuk and the Fortress Mountain Formations. Age groupings are listed as numbers of ages within each "bin”, although since 100 grains were dated for each sample, these numbers are effectively percentages as well.

\begin{tabular}{|c|c|c|c|c|c|c|}
\hline \multirow[b]{2}{*}{ Sample No. } & \multicolumn{6}{|c|}{ SIGNIFICANT GROUPINGS OF DETRITAL AGES } \\
\hline & 251-299 $\mathrm{Ma}^{\mathrm{a}}$ & $500-665 \mathrm{Ma}^{\mathrm{b}}$ & $850-950 \mathrm{Ma}^{\mathrm{c}}$ & $1.00-1.35 \mathrm{Ga}^{\mathrm{d}}$ & $1.80-2.05 \mathrm{Ga}^{\mathrm{e}}$ & $>542 \mathrm{Ma}$ \\
\hline \multicolumn{7}{|c|}{ NANUSHUK FORMATION } \\
\hline 05ASD053 & 1 & 14 & 12 & 24 & 6 & 76 \\
\hline $05 W K W 082$ & 0 & 32 & 14 & 16 & 4 & 82 \\
\hline AVERAGE & $0.5 \%$ & $23 \%$ & $13 \%$ & $20 \%$ & $5 \%$ & $79 \%$ \\
\hline \multicolumn{7}{|c|}{ FORTRESS MOUNTAIN FORMATION } \\
\hline 02MAW009 & 19 & 2 & 5 & 4 & 10 & 40 \\
\hline 02MAW020 & 18 & 14 & 3 & 7 & 13 & 58 \\
\hline 02MAW006 & 10 & 5 & 3 & 4 & 20 & 54 \\
\hline AVERAGE & $16 \%$ & $7 \%$ & $4 \%$ & $5 \%$ & $14 \%$ & $51 \%$ \\
\hline $\begin{array}{l}{ }^{\mathrm{a}} \text { Permian period, based o } \\
{ }^{\mathrm{b}} \text { Globally significant oro } \\
{ }^{\mathrm{c}} \text { Part of the early Neopro } \\
{ }^{\mathrm{d}} \text { Globally significant oro } \\
{ }^{\mathrm{e}} \text { Orosirian period of the }\end{array}$ & $\begin{array}{l}\text { timescale of Ogg } \\
\text { genic episode spann } \\
\text { erozoic } \\
\text { genic episode in the } \\
\text { aleoproteroic, base }\end{array}$ & $\begin{array}{l}\text { g04) } \\
\text { the late Neoproter } \\
\text { esoproterozoic (e.g } \\
\text { n timescale of Ogg }\end{array}$ & $\begin{array}{l}\text { oic - Cambrian (e.g } \\
\text { YcLelland and other } \\
004 \text { ) }\end{array}$ & $\begin{array}{l}\text { Murphy and Nance, } 1 \\
\text { 1996) }\end{array}$ & 91) & \\
\hline
\end{tabular}



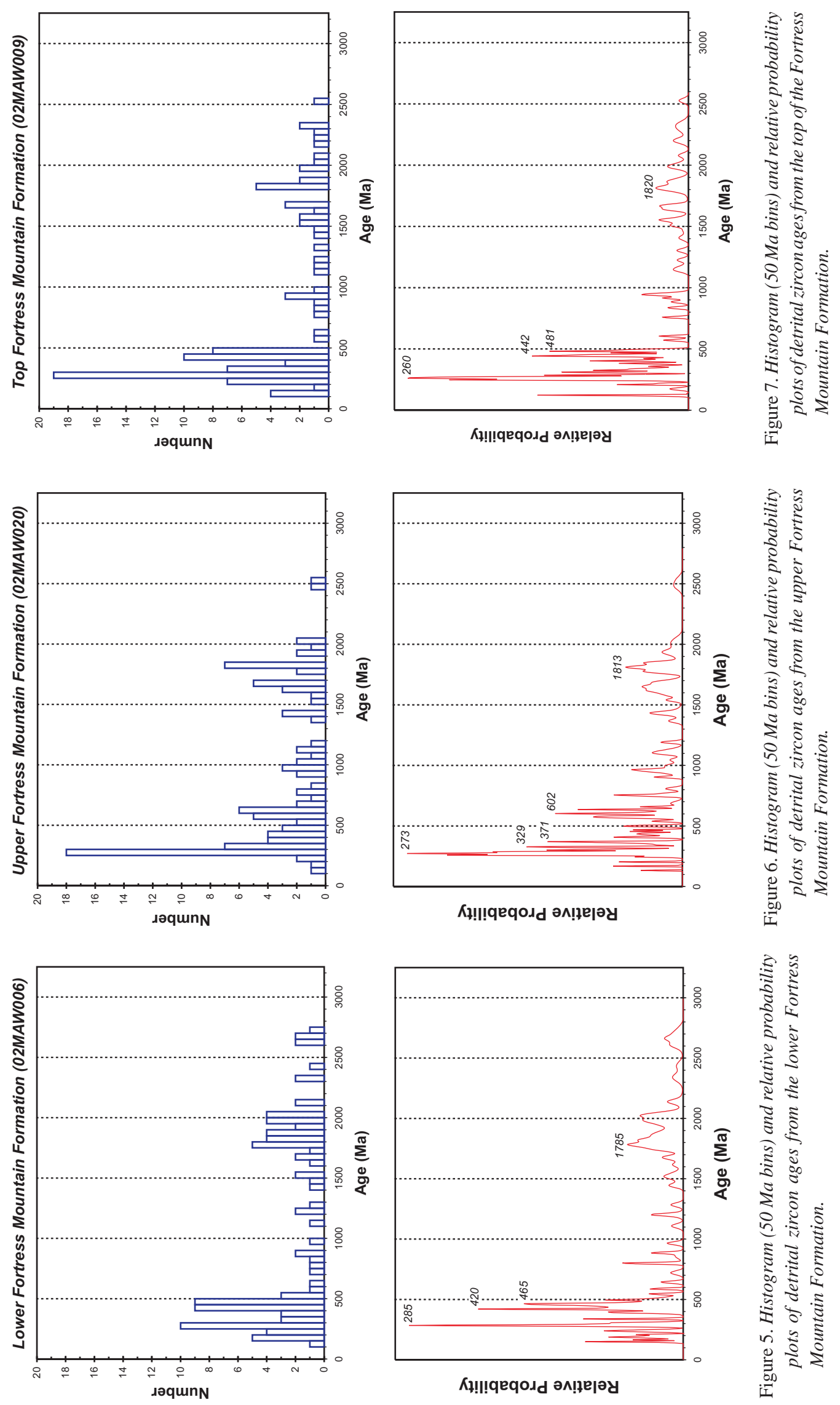

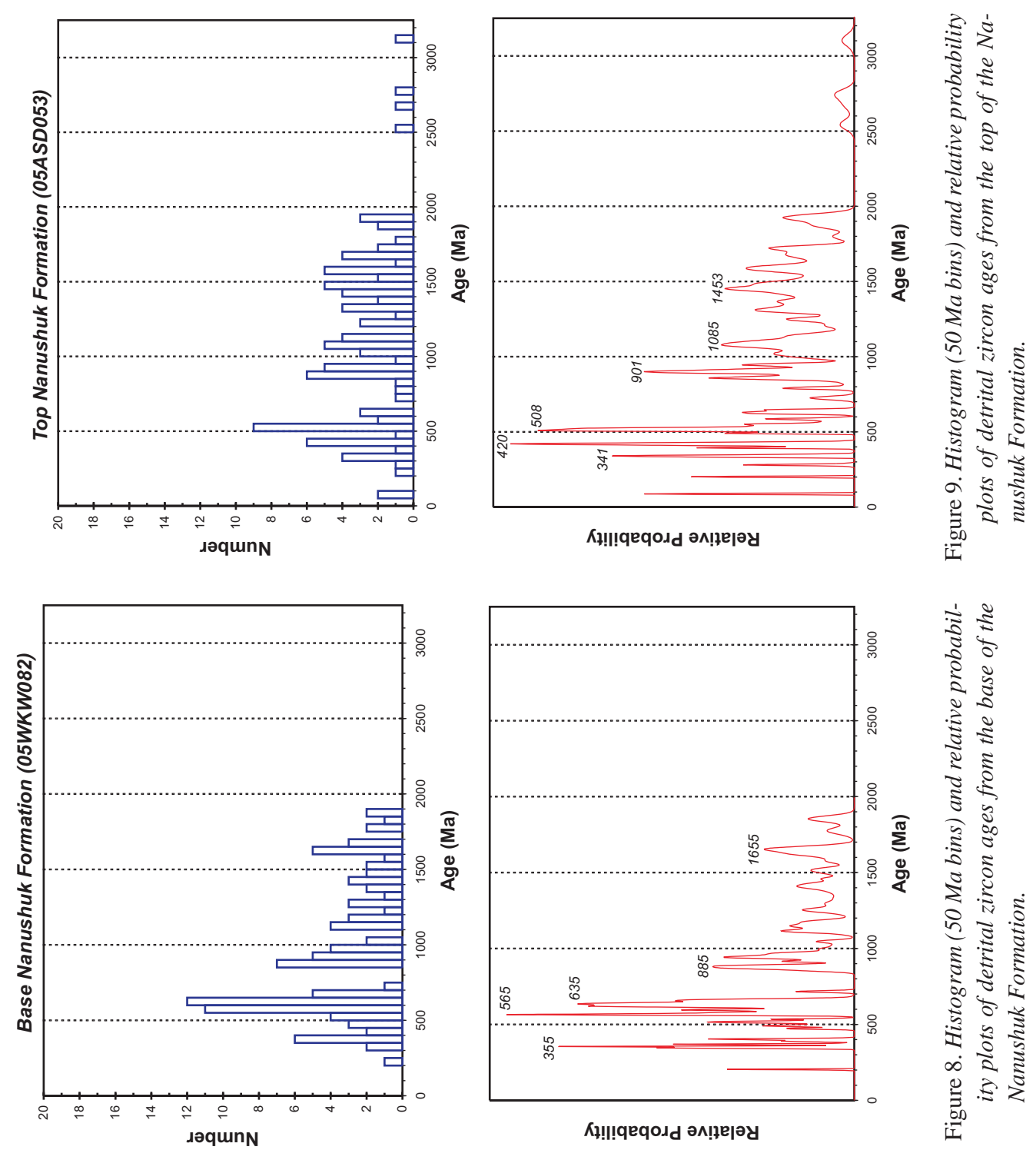

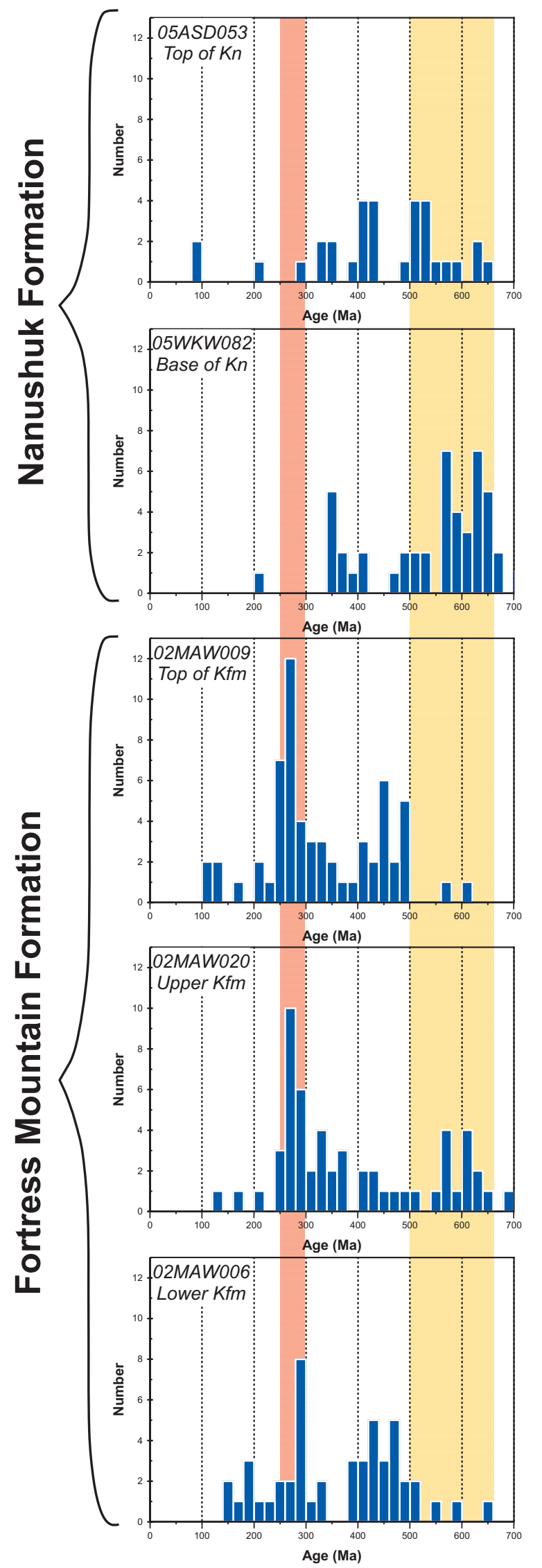

Permian ages

( 251 - $299 \mathrm{Ma})$

late Neoproterozoic - Cambrian "Pan-African" ages ( 500 - $665 \mathrm{Ma})$

Figure 10. Histograms (20 Ma bins) depicting a subset of grain age populations (0-700 Ma). Samples are stacked in interpreted stratigraphic order. Highlighted groupings illustrate the significant differences between Fortress Mountain and Nanushuk Formation samples (see also table 2). "Pan-African" refers to a globally significant orogenic episode (Murphy and Nance, 1991).

balance of these results favors an interpretation that the two units do not represent parts of a single clastic wedge.

Very little $\mathrm{U}-\mathrm{Pb}$ zircon geochronologic data exists for the Brooks Range and precise correlations between these detrital ages and specific units in the fold-and-thrust belt is premature and beyond the scope of this paper. Instead, the more salient, first order result from this study is that the Fortress Mountain and Nanushuk Formations were clearly tapping unique and different source areas and represent discrete phases in the unroofing sequence. This agrees with existing conventional petrographic point-count data noted earlier, which indicated clear differences in framework grain composition between the two formations (Bartsch-Winkler and Huffman, 1988; Molenaar and others, 1988). However, in some respects, the zircon data provide a more robust and quantitative comparison of the two units. It has long been recognized that sandstone mineralogy can be strongly influenced by transport distance (Pettijohn, 1957), particularly the labile components (Mack, 1978) that are abundant in both units. Given the geographic separation of the Fortress Mountain and Nanushuk outcrop belts, it remains possible that the observed differences were simply a function of transport biases. In contrast, durable zircons are unlikely to undergo significant weathering or fractionation along a depositional profile (Morton and Smale, 1991).

Ultimately, these provenance differences have stratigraphic implications and suggest the youngest exposed Fortress Mountain Formation is not correlative with the basal Nanushuk Formation. This interpretation is consistent with most depictions of Cretaceous stratigraphy, which show a tongue of the Torok Formation separating the sandstone-rich Fortress Mountain and Nanushuk sequences (Mull and others, 2003; figs. 3 and 12). The uppermost Fortress Mountain Formation at Castle Mountain records alluvial fan and braided fluvial deposition (Molenaar and others, 1988; Crowder, 1987). Thus, if a succession of Torok mudstones originally overlay this interval, it would represent a transgressive sequence (fig. 12b). This hypothesis is difficult to evaluate due 

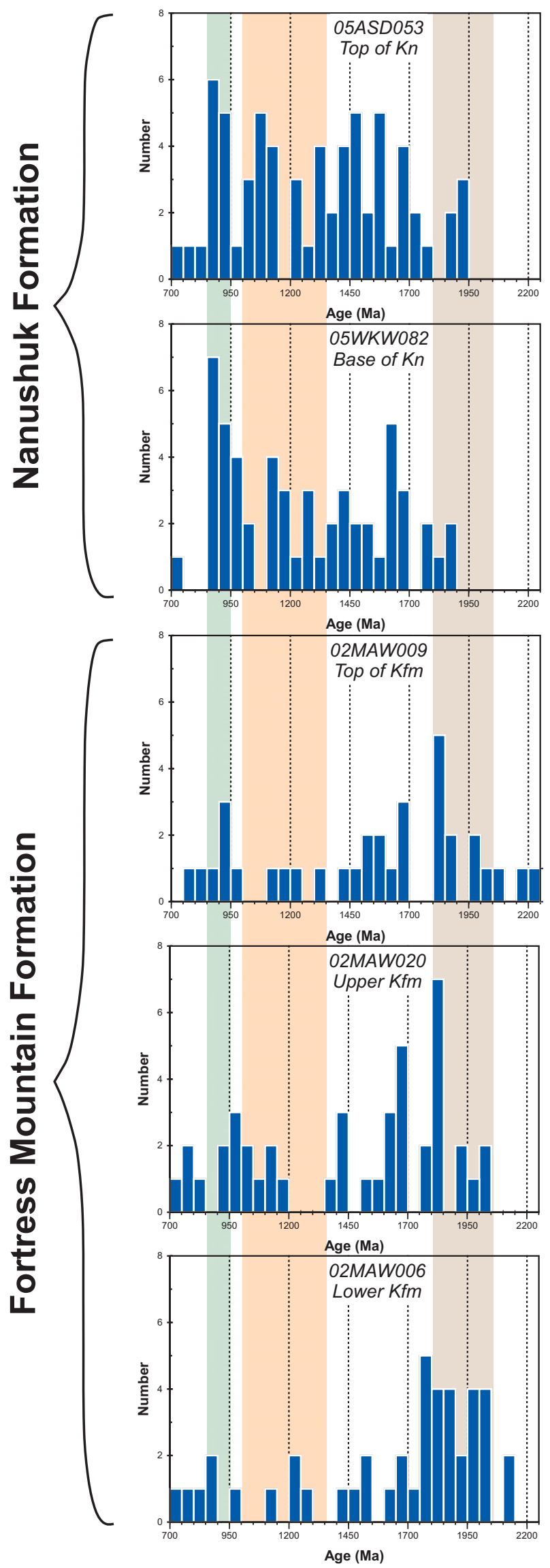

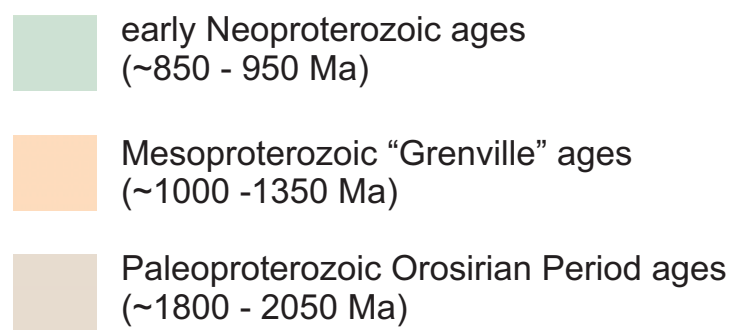

Figure 11. Histograms (50 Ma bins) depicting a subset of grain age populations (700-2250 Ma). Samples are stacked in interpreted stratigraphic order. Highlighted groupings illustrate the significant differences between Fortress Mountain and Nanushuk Formation samples (see also table 2). "Grenville” refers to a globally significant orogenic episode (McLelland and others, 1996); Orosirian is a Mesoproterozoic period (Ogg, 2004).

to the lack of exposed formation tops in Fortress Mountain exposures (fig. 12a; see also figure 4a of Bird and Molenaar, 1992). However, a few regional observations have cited evidence for an upward deepening at the top of the Fortress Mountain Formation. For example, in the Ekakevik Mountain area (fig. 1), Hunter and Fox (1976) noted that the formation generally fines upward and, where best exposed, the top of the formation was characterized by transgressive shallow marine facies overlying nonmarine conglomerate. Farther west, between Poko and Igloo mountains (fig. 1), Mull (1985) inferred a gradational contact between the Fortress Mountain Formation and overlying fine-grained facies of the Torok Formation.

A major flood back of Torok slope facies over nonmarine-marginal marine Fortress Mountain Formation was recently recognized in the Siksikpuk River area (labeled as Kfm-Kto contact on fig. 2; Houseknecht and others, 2007; Peapples and others, 2007). However, this section is here interpreted as relatively low in the composite Fortress Mountain succession (Patton and Tailleur, 1964), suggesting that the transgressive event is intra-Fortress Mountain, rather than marking the regional top of the formation. It is also possible there is regional variation in the position of the top of the Fortress Mountain Formation and that flooding of the Torok Formation across the Fortress Mountain Formation was diachronous locally, varying according to paleotopography across the complex orogenic wedge (Wartes and Swenson, 2005). Similarly complex relationships are known from the better-studied Upper Cretaceous foreland basin strata of the Western Interior Seaway (Krystinik and DeJarnett, 1995).

Existing data do not unequivocally rule out a scenario whereby now-eroded sections of the Fortress Mountain Formation once existed above Castle Mountain and formed part of a unified prograding clastic wedge that 
graded northward into the lower Nanushuk deltas (fig. 12c; see also figure 25.3c in Molenaar, 1988). However, if such a section existed, then a substantial upsection change in provenance would be required within the uppermost proximal Fortress Mountain Formation. Based on available data (including that presented here), it seems more probable that the Fortress Mountain and Nanushuk Formations are regionally separated by an intervening tongue of the Torok Formation (fig. 12b), possibly recording a basin-scale change in the balance between sediment supply and newly created accommodation.

The Torok Formation can be generically subdivided into lower and upper parts, roughly corresponding to proximal Fortress Mountain and Nanushuk Formations, respectively (Mull and others, 2003; fig. 3). If a tongue of Torok separates these two progradational sequences (fig. 12b) —an interpretation that is favored here-then it may prove useful to consider a tripartite genetic subdivision of the formation (fig. 13). It is difficult to evaluate this proposed subdivision in the outcrop belt where distinctions between lower, middle, and upper parts of the formation are hampered by: (1) inadequate biostratigraphic resolution, (2) non-unique, fine-grained facies, (3) discontinuous exposures, and (4) complex structure (Patton and Tailleur, 1964; Mull, 1985; Molenaar and others, 1988; Houseknecht and Schenk, 2007; Houseknecht and others, 2007). Regional seismic and well data indicate that an older succession of Brookian rocks exists beneath the Nanushuk-related Torok clinoforms (Molenaar, 1988). In the northern foothills, Houseknecht and Schenk (2001) document that this older Torok "foredeep wedge" was derived from the west and traced individual Torok clinoforms into Nanushuk topsets. However, this wedge continues to thicken dramatically southward, probably including southerly sourced Fortress Mountain-related lower(?) Torok facies (Cole and others, 1997; Molenaar, 1988). Regardless, in light of the strong differences in detrital zircon ages within the proximal Fortress Mountain and Nanushuk Formations, it seems likely that the affinity of isolated Torok samples could be reliably assessed with the technique outlined in this study.

The new provenance data presented here confirm that the Fortress Mountain and
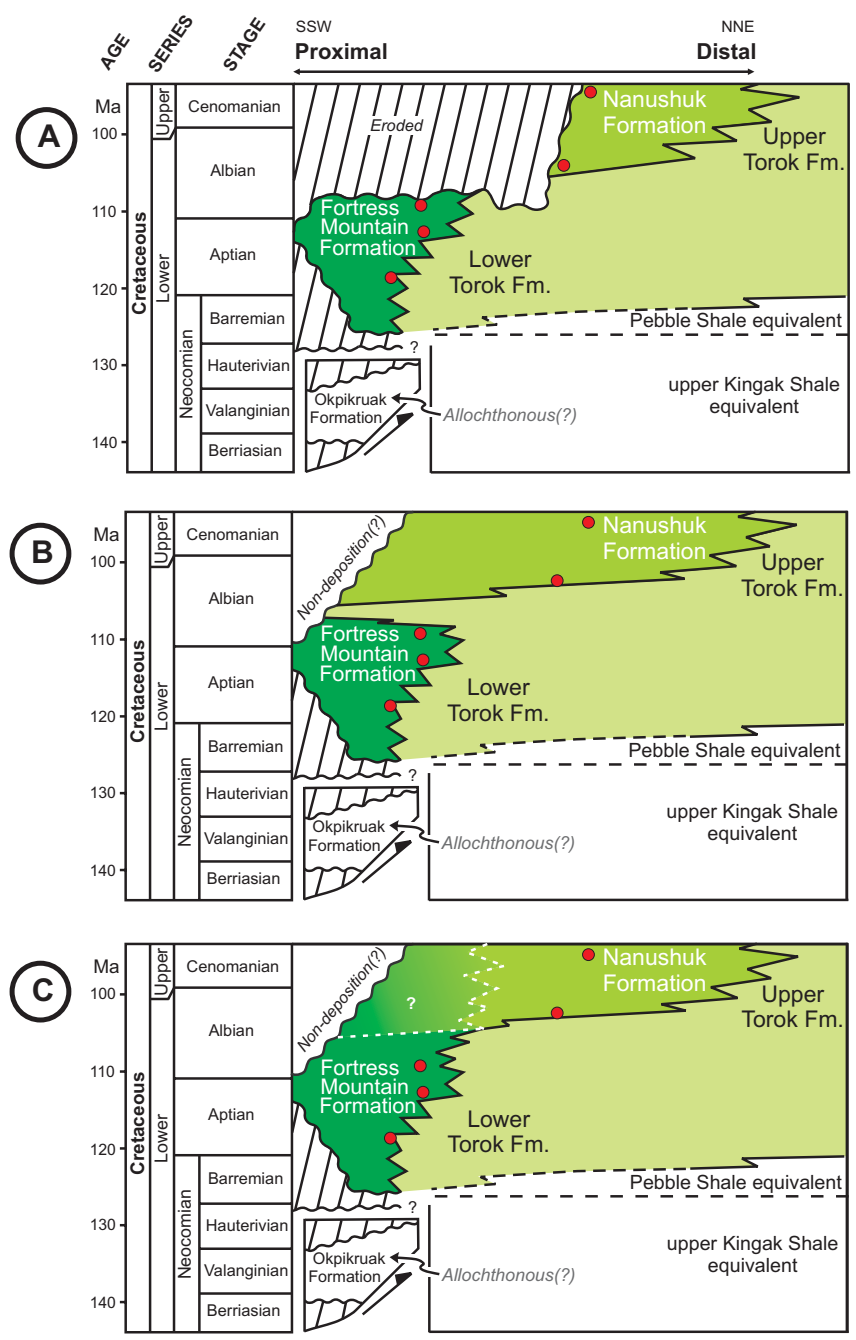

Figure 12. Chronostratigraphic diagrams illustrating relationships between the Fortress Mountain, Nanushuk, and Torok Formations discussed in the text. Approximate sample positions shown by red dots. (A) Depiction of the observed spatial context of Fortress Mountain and Nanushuk exposures, highlighting the ambiguity of proposed stratigraphic correlations between the two units. This diagram contrasts with the common schematic representation of Early Cretaceous stratigraphy (Mull and others, 2003; fig. 3) and emphasizes that the top of the Fortress Mountain Formation is a Holocene erosion surface and that the Nanushuk Formation cannot be demonstrated to overlie the Fortress Mountain Formation based on field evidence alone. On the basis of the available constraints discussed in the text, this figure interprets the exposed Fortress Mountain Formation as entirely older than the Nanushuk Formation in this area. (B \& C) Portrayal of two possible stratigraphic scenarios as they would have appeared at the close of Nanushuk deposition: (B) proposes a retrogradational tongue of Torok separated the Fortress Mountain and Nanushuk Formations (model favored in this study), while (C) illustrates a model where the Fortress Mountain and Nanushuk Formations represent a continuous northward-prograding clastic wedge (see also figure 25.3c in Molenaar, 1988). 


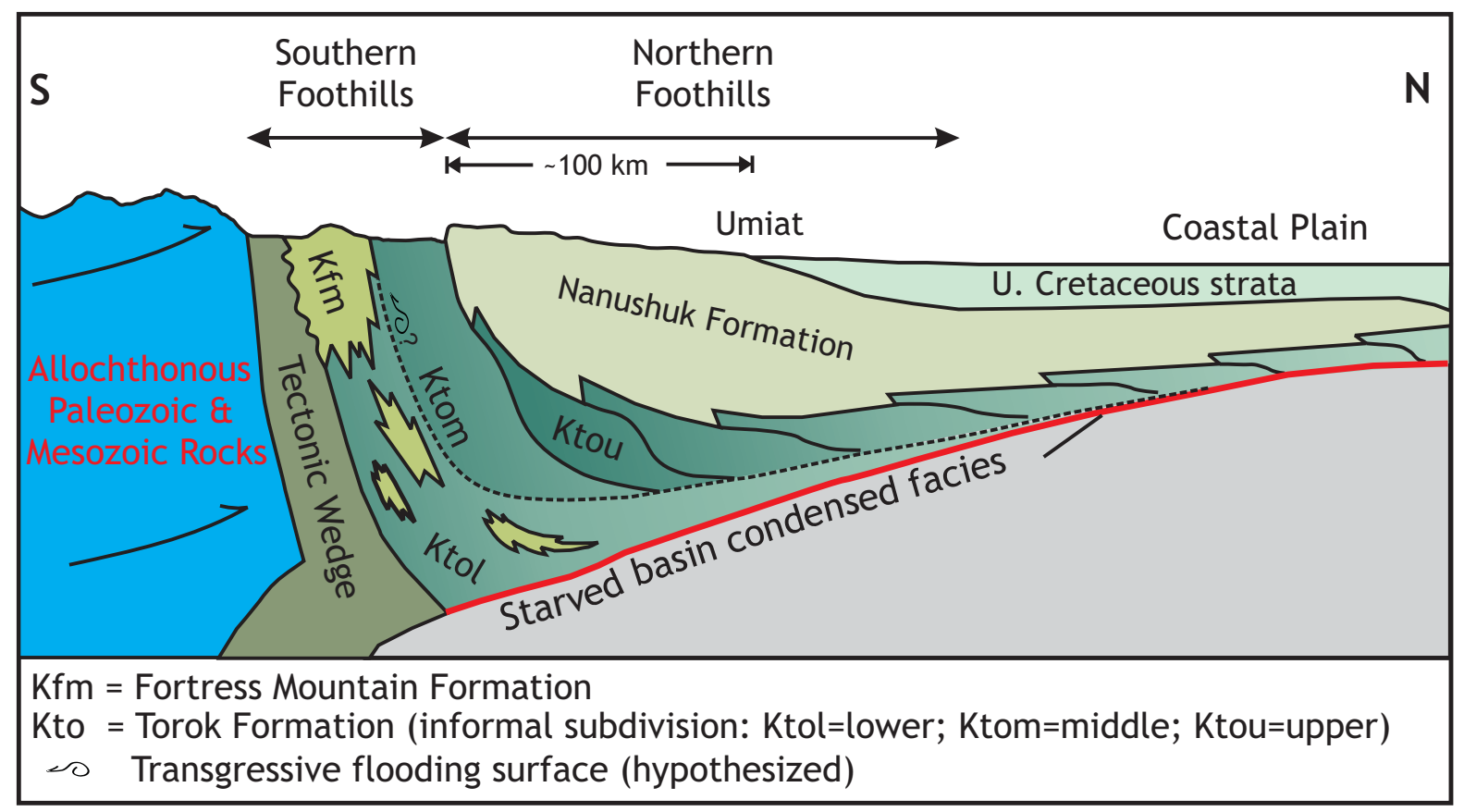

Figure 13. Schematic cross section of the Colville Basin (modified from Mull, 1985, and Houseknecht and Schenk, 2001). The middle Torok is speculated to be a retrogradational package separating the Fortress Mountain and Nanushuk Formations.

Nanushuk Formations were clearly derived from different sources. Provided the two units both record unroofing of the nearby ancestral Brooks Range, it follows that the exposed Fortress Mountain Formation represents an entirely older depositional system than the Nanushuk topsets (as shown in fig. 12a). However, it remains possible that the two units are partly coeval and that the detrital zircon data reflects two different major sediment dispersal systems - transverse, Brooks Range-derived Fortress Mountain Formation and axially fed Nanushuk facies tapping a different source region to the west. Even in better-studied foreland basins, identifying the relative roles of axial versus transverse systems is difficult (Clevis and others, 2004). Farther north, in central NPRA (fig. 1), seismically mapped shelf margins indicate the Nanushuk-Torok depositional system is fed principally out of the west (Molenaar, 1988; Houseknecht and Schenk, 2001). However, the origin of Nanushuk topsets in the area sampled in this study were most likely sourced from transverse, north-flowing rivers as indicated by paleocurrent data as well as contrasting deltaic style and provenance relative to the demonstrably western-sourced axial deltaic system (Huffman and others, 1988; Molenaar, 1988; LePain and others, in press).

The focus of this paper has been the stratigraphic implications of a modest new detrital zircon data set. Future papers will examine the potential sources of various zircon age populations and the broader tectonic implications of these data. However, it is worth noting that the marked change in provenance outlined in this study occurred at approximately the early to middle Albian boundary, a time characterized by significant tectonic events in the Brooks Range hinterland (Vogl, 2002). In other words, the provenance changes may reflect discrete tectonicallydriven exhumation and orogen-wide reorganization of drainages.

\section{CONCLUSIONS}

New detrital zircon age data indicate the Fortress Mountain and Nanushuk Formations in the central Brooks Range foothills were sourced from unique and different provenances. Significantly different populations of grain ages suggest the Fortress Mountain and Nanushuk depositional systems were not part of a unified north-northeasterly prograding clastic wedge. Instead, the youngest exposed Fortress Mountain Formation is here interpreted to be entirely older than the Nanushuk Formation. Based on available data, it is inferred that the Fortress Mountain and Nanushuk Formations are separated by a transgressive tongue of the Torok Formation, although more data are needed to definitively reject alternate hypotheses. In particular, additional subsurface information will be required to document stratigraphic relationships that are presently ambiguous. 


\section{ACKNOWLEDGMENTS}

The impetus for this study came from a number of outcrop discussions with A. Carroll, who, unbiased by any North Slope geological dogma, posed a number of insightful questions regarding established Brookian stratigraphic relationships, including, “Are you sure the Fortress Mountain and Nanushuk Formations aren’t, in part, correlative?” The ideas presented here also benefited from numerous discussions with D. LePain, R. Gillis, T. Moore, P. Decker, G. Mull, R. Reifenstuhl, R. Swenson, W. Wallace, D. Houseknecht, and P. O’Sullivan. A version of figure 13 was kindly provided by D. LePain. Funding for part of the original work in the Castle Mountain area was generously supplied to the University of Wisconsin by Anadarko Petroleum Corporation. DGGS studies in the foothills are supported by industry contributions from Anadarko, FEX, BG Alaska, Chevron, Petro-Canada, Pioneer Natural Resources, ENI, Shell, and ConocoPhillips. Funding for DGGS geologic mapping in the Siksikpuk River area was provided by the state of Alaska and the U.S. Geological Survey National Cooperative Geologic Mapping Program (award numbers 04HQAG0061 and 05HQAG0025). This paper benefitted from constructive review comments by Bob Gillis.

\section{REFERENCES}

Ahlbrandt, T.S., ed., 1979, Preliminary geologic, petrologic, and paleontologic results of the study of Nanushuk Group rocks, North Slope, Alaska: U.S. Geological Survey Circular 794, 163 p.

Bartsch-Winkler, S., and Huffman, A.C., Jr., 1988, Sandstone petrography of the Nanushuk Group and Torok Formation, in Gryc, George, ed., Geology and exploration of the National Petroleum Reserve in Alaska, 1974 to 1982: U.S. Geological Survey Professional Paper 1399, p. 801-831.

Bird, K.J., and Molenaar, C.M., 1992, The North Slope foreland basin, Alaska, in Macqueen, R.W., and Leckie, D.A., eds., Foreland basins and fold belts: AAPG Memoir 55, p. 363-393.

Chang, Z., Vervoort, J.D., McClelland, W.C., and Knaack, C., 2006, U-Pb dating of zircon by LA-ICP-MS: Geochemistry, Geophysics, Geosystems, v. 7, no. 5, Q05009.

Clevis, Q., DeBoer, P.L., and Nijman, W., 2004, Differentiating the effect of episodic tectonism and eustatic sea-level fluctuations in foreland basins filled by alluvial fans and axial deltaic systems: insights from a threedimensional stratigraphic forward model: Sedimentology, v. 51, p. 809-835.

Cole, F.E., Bird, K.J., Toro, J., Roure, F., O’Sullivan, P.B., Pawlewicz, M.J., and Howell, D.G., 1997, An integrated model for the frontal Brooks Range and Colville Basin 250 km west of the Trans-Alaska Crustal Transect: Journal of Geophysical Research, v. 102, p. 20,685-20,708.

Crowder, R.K., 1987, Cretaceous basin to shelf transition in northern Alaska; deposition of the Fortress Mountain Formation, in Tailleur, I.L., and Weimer, P., eds., Alaskan North Slope geology: Pacific Section, SEPM, Bakersfield, CA, v. 50, p. 449-458.

—Deposition of the Fortress Mountain Formation, in Mull, C.G., and Adams, K.E., eds., Dalton Highway, Yukon River to Prudhoe Bay, Alaska: Alaska Division of Geological \& Geophysical Surveys Guidebook 7, v. 2, p. 293-301.

Detterman, R.L., 1956, New and redefined nomenclature of Nanushuk Group: AAPG Bulletin, v. 40, p. 233244.

Dickinson, W.R., and Gehrels, G.E., 2003, U-Pb ages of detrital zircons from Permian and Jurassic eolian sandstones of the Colorado Plateau, USA; paleogeographic implications: Sedimentary Geology, v. 163, p. 29-66.

Dodson M.H., Compston, W., Williams, I.S., and Wilson, J.F., 1988, A search for ancient detrital zircons in Zimbabwean sediments: Journal of the Geological Society of London, v. 145, p. 977-983.

Fedo, C.M., Sircombe, K.N., and Rainbird, R.H., 2003, Detrital zircon analysis of the sedimentary record: Reviews in Mineralogy and Geochemistry, v. 53, p. 277-303.

Gehrels, G.E., Valencia, V., and Pullen, A., 2006, Detrital zircon geochronology by laser-ablation multicollector ICPMS at the Arizona Laser-Chron Center, in Olszewski, T., and Huff, W., eds., Geochronology; Emerging opportunities: Philadelphia, Pennsylvania, Paleontological Society Short Course, p. 1-10.

Gillis, R.J., Gehrels, G.E., Ruiz, J., and de Dios Gonzalez, L.A.F., 2005, Detrital zircon provenance of Cambrian-Ordovician and Carboniferous strata of the Oaxaca terrane, southern Mexico: Sedimentary Geology, v. 182, p. 87-100.

Houseknecht, D.W, and Schenk, C.J., 2001, Depositional sequences and facies in the Torok Formation, National Petroleum Reserve-Alaska (NPRA), in Houseknecht, D.W., ed., NPRA Core Workshop; Petroleum Plays and Systems in the National Petroleum Reserve Alaska: SEPM Core Workshop (June 2001), no. 21,, p. 179-199. 
Houseknecht, D.W, and Schenk, C.J., 2007, Outcrops of turbidite channel facies in the Torok Formation; reservoir analogs for the Alaska North Slope, in Nilsen, T., Shew, R.D., Steffens, G.S., and Studlick, J.R.J., eds., An Atlas of Deepwater Outcrops; Models and Analogs: American Association of Petroleum Geologists Studies in Geology v. 56, p. 373-377.

Houseknecht, D.W., and Bird, K.J., 2006, Oil and gas resources of the Arctic Alaska petroleum province: U.S. Geological Survey Professional Paper 1732-A, 11 p.

Houseknecht, D.W., Schenk, C.J., and Wartes, M.A., 2007, Sedimentology and sequence stratigraphy of the Lower Cretaceous Fortress Mountain and Torok Formations exposed along the Siksikpuk River, north-central Alaska, in Haeussler, P.J., and Galloway, J.P., eds., Studies by the U.S. Geological Survey in Alaska, 2006: U.S. Geological Survey Professional Paper 1739-D, 27 p., 1 plate.

Huffman, A.C., Jr., ed., 1985, Geology of the Nanushuk Group and related rocks, North Slope, Alaska: U.S. Geological Survey Bulletin 1614, 129 p.

Huffman, A.C., Jr., Ahlbrandt, T.S., and Bartsch-Winkler, Susan, 1988, Sedimentology of the Nanushuk Group, North Slope, in Gryc, George, ed., Geology and exploration of the National Petroleum Reserve in Alaska, 1974 to 1982: U.S. Geological Survey Professional Paper 1399, p. 281-298.

Hunter, R.E., and Fox, J.E., 1976, Interpretation of depositional environments in the Fortress Mountain Formation, central Arctic Slope: U.S. Geological Survey Circular 733, p. 30-31.

Imlay, R.W., 1961, Characteristic Lower Cretaceous megafossils from northern Alaska: U.S. Geological Survey Professional Paper 335, 74 p.

Johnsson, M.J., and Sokol, N.K., 2000, Stratigraphic variation in petrographic composition of Nanushuk Group sandstones at Slope Mountain, North Slope, Alaska, in Kelley, K.D., and Gough, L.P., eds., Geologic studies in Alaska by the U.S. Geological Survey, 1998: U.S. Geological Survey Professional Paper 1615, p. 83-100.

Kelley, J.S., 1990, Generalized geologic map of the Chandler Lake Quadrangle, north-central Alaska: U.S. Geological Survey Miscellaneous Field Studies Map 2144A, 1 sheet, 19 p.

Krystinik, L.F., and DeJarnett, B., 1995, Lateral variability of sequence stratigraphic framework in the Campanian and Early Maastrichtian of the Western Interior Seaway, in Van Wagoner, J.C., and Bertram, G.T., eds., Sequence stratigraphy of foreland basin deposits; Outcrop and subsurface examples from the Cretaceous of North America: American Association of Petroleum Geologists Memoir, no. 64, p. 11-26.

LePain, D.L., McCarthy, P.J., and Kirkham, R., 2008, Sedimentology and sequence stratigraphy of the Nanushuk Formation in the central Brooks Range foothills, northern Alaska: Alaska Division of Geological \& Geophysical Surveys Report of Investigation, in press.

Ludwig, K.R., 2005, Isoplot/EX rev. 3.32; A geochronological toolkit for Microsoft Excel: Berkeley Geochronology Center Special Publication 4.

Mack, G.H., 1978, The survivability of labile light-mineral grains in fluvial, aeolian, and littoral marine environments; the Permian Cutler and Cedar Mesa formations, Moab, Utah: Sedimentology, v. 25, no. 5, p. 587-603.

McLearn, F.H., 1945, Revision of the Lower Cretaceous of the western interior of Canada: Geological Survey of Canada Paper 44-17 (2nd ed.), 14 p., 2 tables, 12 plates.

McLelland, J., Daly, J.S., and McLelland, J.M., 1996, The Grenville Orogenic Cycle (ca. 1350-1000 Ma); an Adirondack perspective: Tectonophysics, v. 265, p. 1-28.

Molenaar, C.M., 1988, Depositional history and seismic stratigraphy of Lower Cretaceous rock in the National Petroleum Reserve in Alaska and adjacent areas, in Gryc, G., editor, Geology and exploration of the National Petroleum Reserve in Alaska, 1974-1982: U.S. Geological Survey Professional Paper 1399, p. 593-621.

Molenaar, C.M., Egbert, R.M., and Krystinik, L.F., 1988, Depositional facies, petrography, and reservoir potential of the Fortress Mountain Formation (Lower Cretaceous), central North Slope, Alaska, in Gryc, G., ed., Geology and Exploration of the National Petroleum Reserve in Alaska, 1974-1982: U.S. Geological Survey Professional Paper 1399, p. 257-280.

Moore, T.E., Wallace, W.K., Bird, K.J., Karl, S.M., Mull, C.G., and Dillon, J.T., 1994, Geology of northern Alaska, in Plafker, G., and Berg, H.C., eds., The Geology of North America, v. G-1, The Geology of Alaska: Boulder, CO, Geological Society of America, p. 49-140.

Moore, T.E., Potter, C.J., O’Sullivan, P.B., Shelton, K.L., and Underwood, M.B., 2004, Two stages of deformation and fluid generation for the central Brooks Range fold and thrust belt, northern Alaska, in Swennen, R.A.J., Roure, Francois, and Granath, J.W., eds., Deformation, fluid flow, and reservoir appraisal in foreland fold and thrust belts: AAPG Hedberg Series, no. 1, p. 157-186. 
Morton, A.C., and Smale, D., 1991, The effects of transport and weathering on heavy minerals from the Cascade River, New Zealand: Sedimentary Geology, v. 68, p. 117-123.

Mull, C.G., 1985, Cretaceous tectonics, depositional cycles, and the Nanushuk Group, Brooks Range and Arctic Slope, Alaska, in Huffman, A.C., ed., Geology of the Nanushuk Group and related rocks, North Slope, Alaska: U.S. Geological Survey Bulletin 1614, p. 7-36.

Mull, C.G, Houseknecht, D.W., and Bird, K.J., 2003, Revised Cretaceous and Tertiary stratigraphic nomenclature in the Colville Basin, northern Alaska: U.S. Geological Survey Professional Paper 1673, 51 p.

Murphy, J.B., and Nance, R.D., 1991, Supercontinent model for the contrasting character of Late Proterozoic orogenic belts: Geology, v. 19, p. 469-472.

Ogg, J.G., 2004, Status of divisions of the International Geologic Time Scale: Lethaia, v. 37, p. $183-199$.

Patton, W.W., and Tailleur, I.L., 1964, Geology of the Killik-Itkillik region, Alaska: U.S. Geological Survey Professional Paper 303G, p. 409-500.

Peapples, P.R., Wallace, W.K., Wartes, M.A., Swenson, R., Mull, C.G., Dumoulin, J.A., Harris, E.E., Finzel, E.S., Reifenstuhl, R.R., and Loveland, A.L., 2007, Geologic map of the Siksikpuk River area, Brooks Range northern foothills, Alaska: Alaska Division of Geological \& Geophysical Surveys Preliminary Interpretive Report 2007-1, 1 sheet, scale 1:63,360.

Pettijohn, F.J., 1957, Sedimentary Rocks: 2nd ed., New York, Harper and Bros., 718 p.

Vogl, J.J., 2002, Late-orogenic backfolding and extension in the Brooks Range collisional orogen, northern Alaska: Journal of Structural Geology, v. 24, p. 1,753-1,776.

Wallace, W.K., Duncan, A.S. Peapples, P.R., Swenson, R.F., Wartes, M.A., O’Sullivan, P.B., and Finzel, E.S., 2006, Geometry and evolution of the frontal part of an orogenic wedge, central Brooks Range Foothills, Alaska: Geological Society of America Abstracts with Program, v. 38, no. 5, p. 24.

Wartes, M.A., 2008, Measured section and facies analysis of the Lower Cretaceous Fortress Mountain Formation, Atigun Syncline, northern Alaska, in Wartes, M.A., and Decker, P.L., eds, Preliminary results of recent geologic field investigations in the Brooks Range foothills and North Slope, Alaska: Alaska Division of Geological \& Geophysical Surveys Preliminary Interpretive Report 2008-1, p. 11-24, 1 sheet.

Wartes, M.A., and Swenson, R.F., 2005, New constraints on the structural and stratigraphic development of the proximal Colville foreland basin; Implications for burial history and oil and gas exploration in the central Brooks Range foothills, northern Alaska, in GSA, Cordilleran Section, 101st annual meeting: AAPG, Pacific Section, 80th annual meeting, Abstracts with Programs, v. 37, no. 4, p. 92-93.

Wartes, M.A., O’Sullivan, P.B., and Carroll, A.R., 2006, Enigmatic Permian U-Pb zircon ages from igneous clasts found in mid-Cretaceous deposits of the Colville Foreland Basin, northern Alaska: Geological Society of America Abstracts with Programs, v. 38, no. 5, p. 89. 
This page has intentionally been left blank. 


\section{Text for reports with appendices:}

This appendix is included in this PDF document for the reader's convenience.

In the full publication, the appendices and sheets are placed at the conclusion of all of the text. The separation of the appendices and sheets from their chapter in the full publication determines the page numbers; thus, you will find that the page numbers for this smaller piece of the larger document are not sequential. 


\section{APPENDIX C-1}

\section{ANALYTICAL DATA AND CALCULATED AGES}



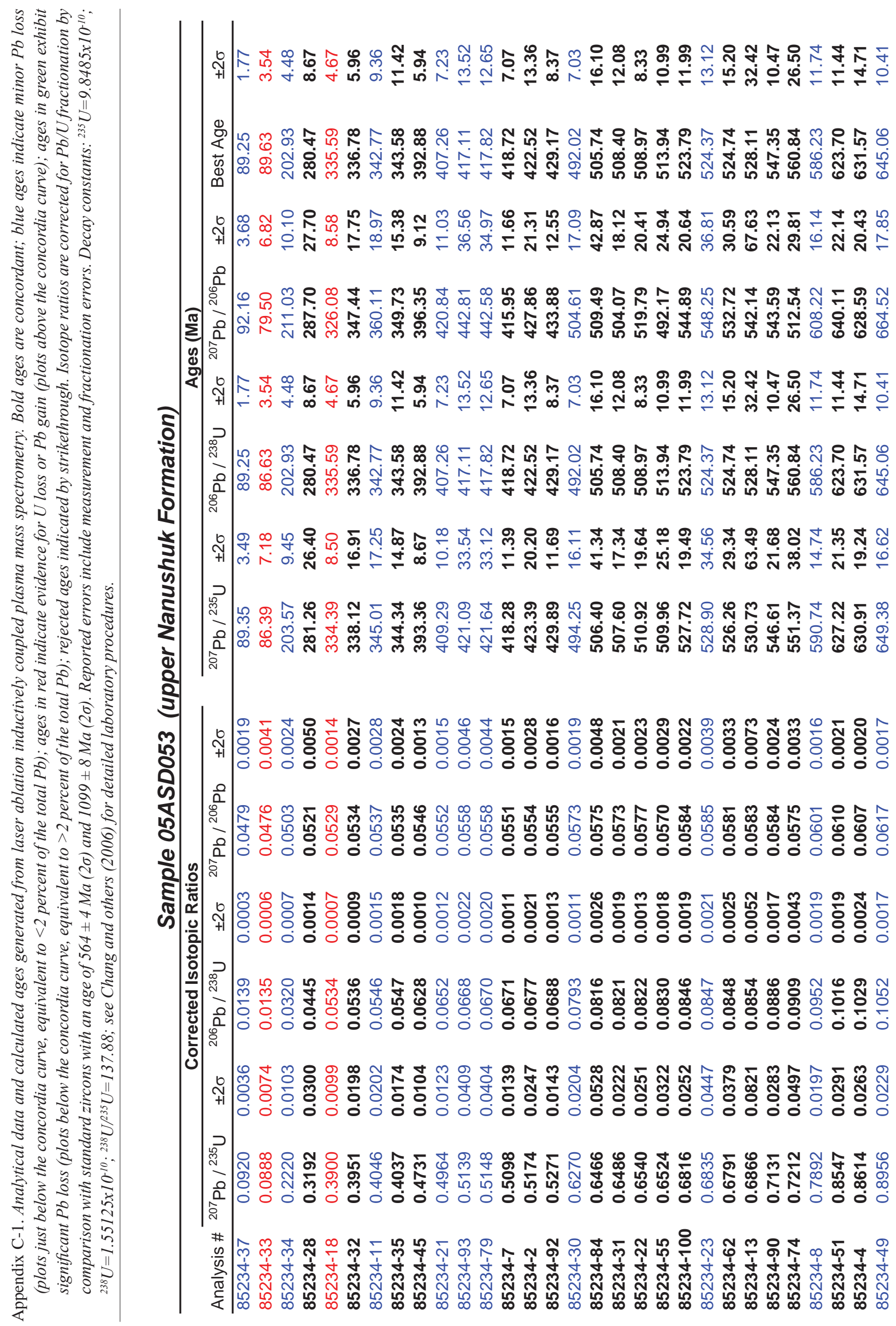


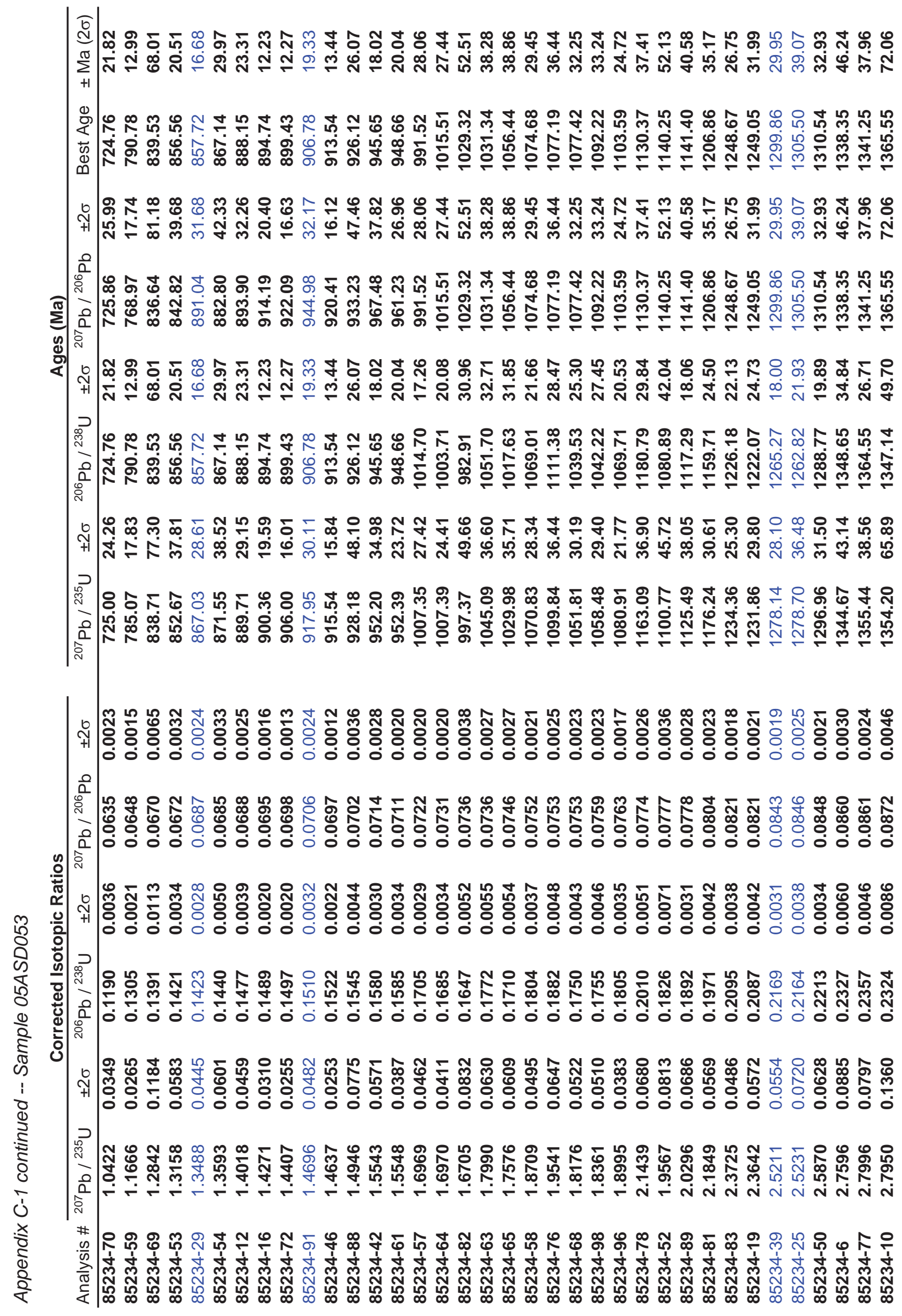




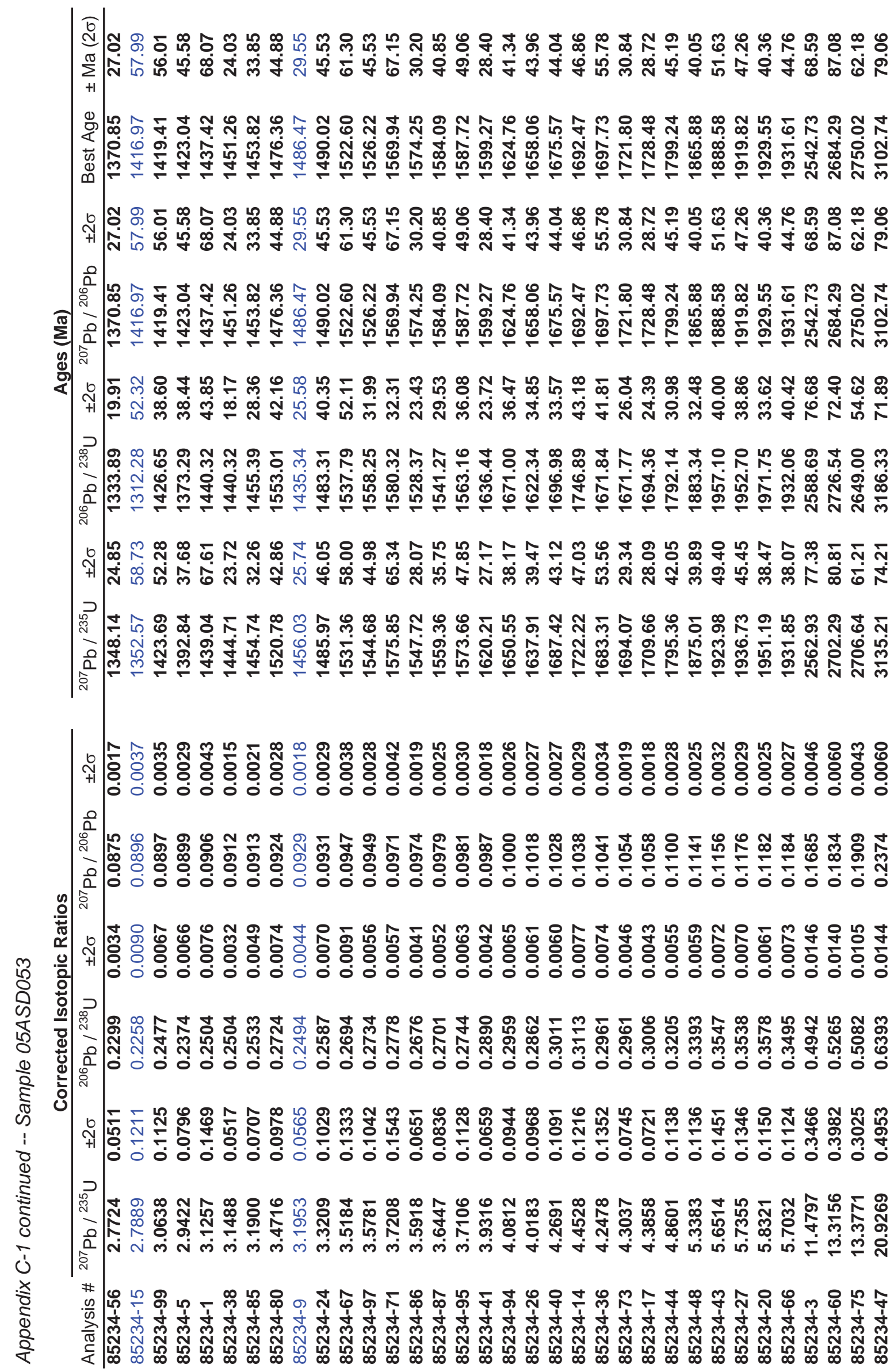




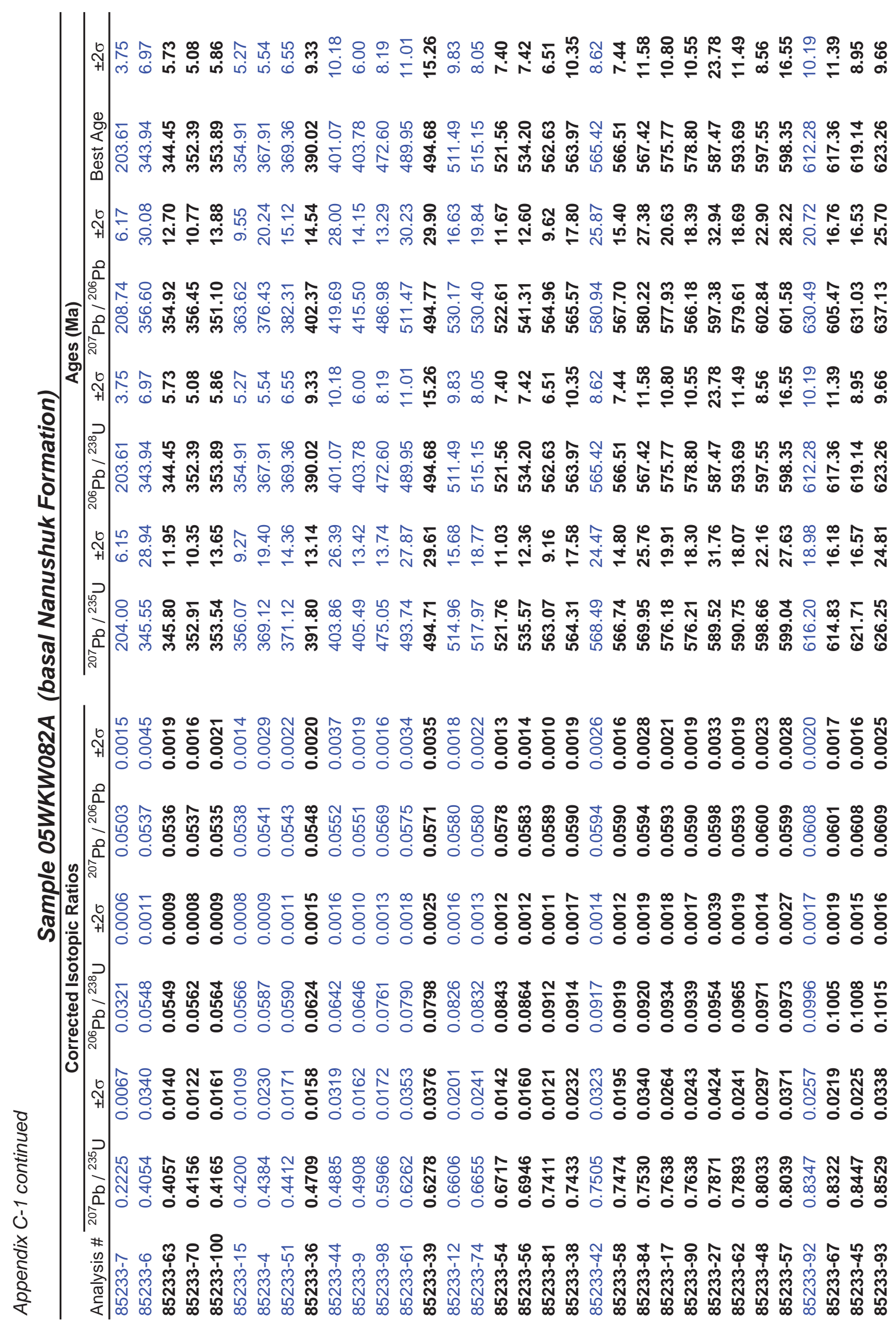




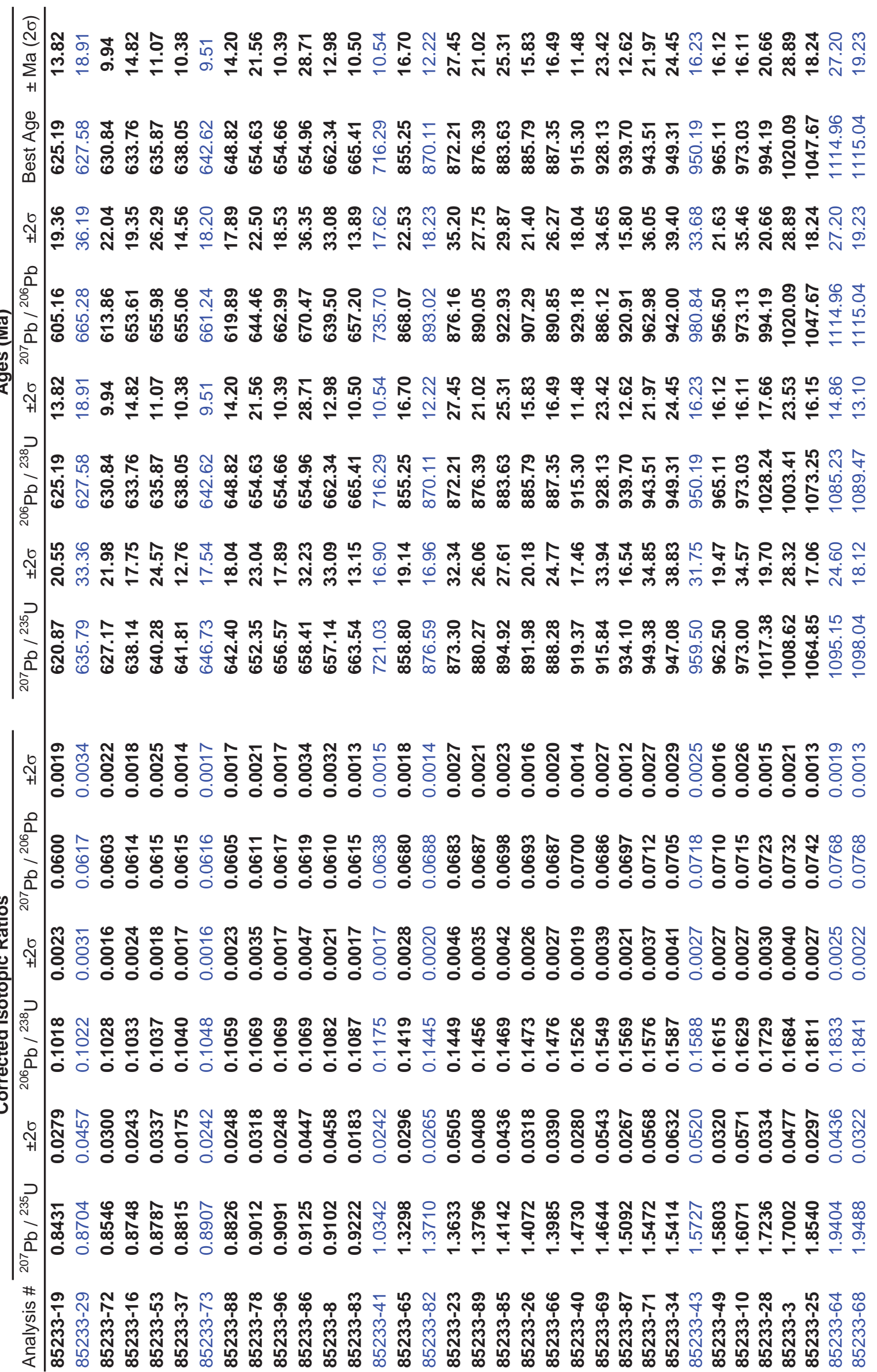




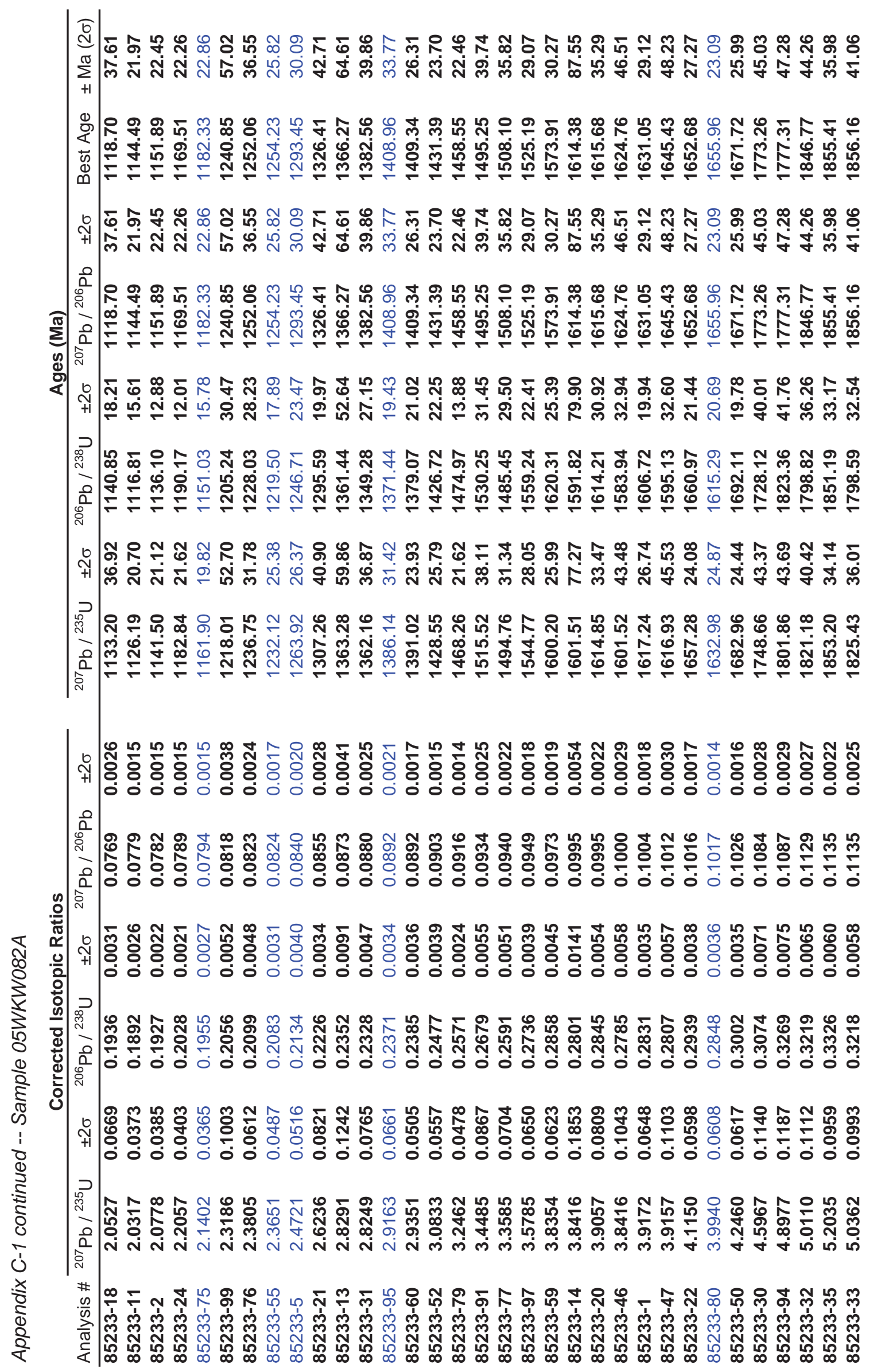




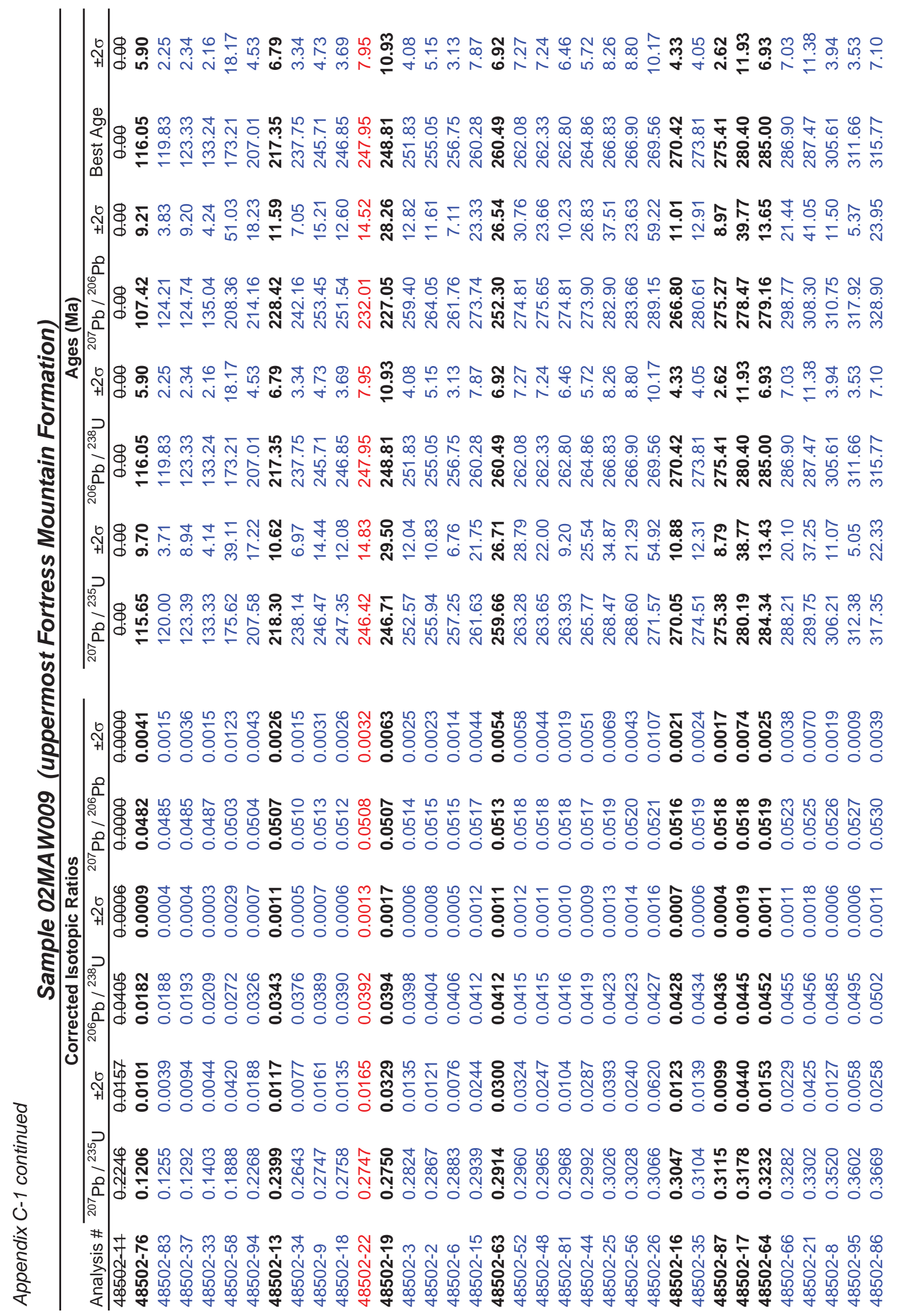




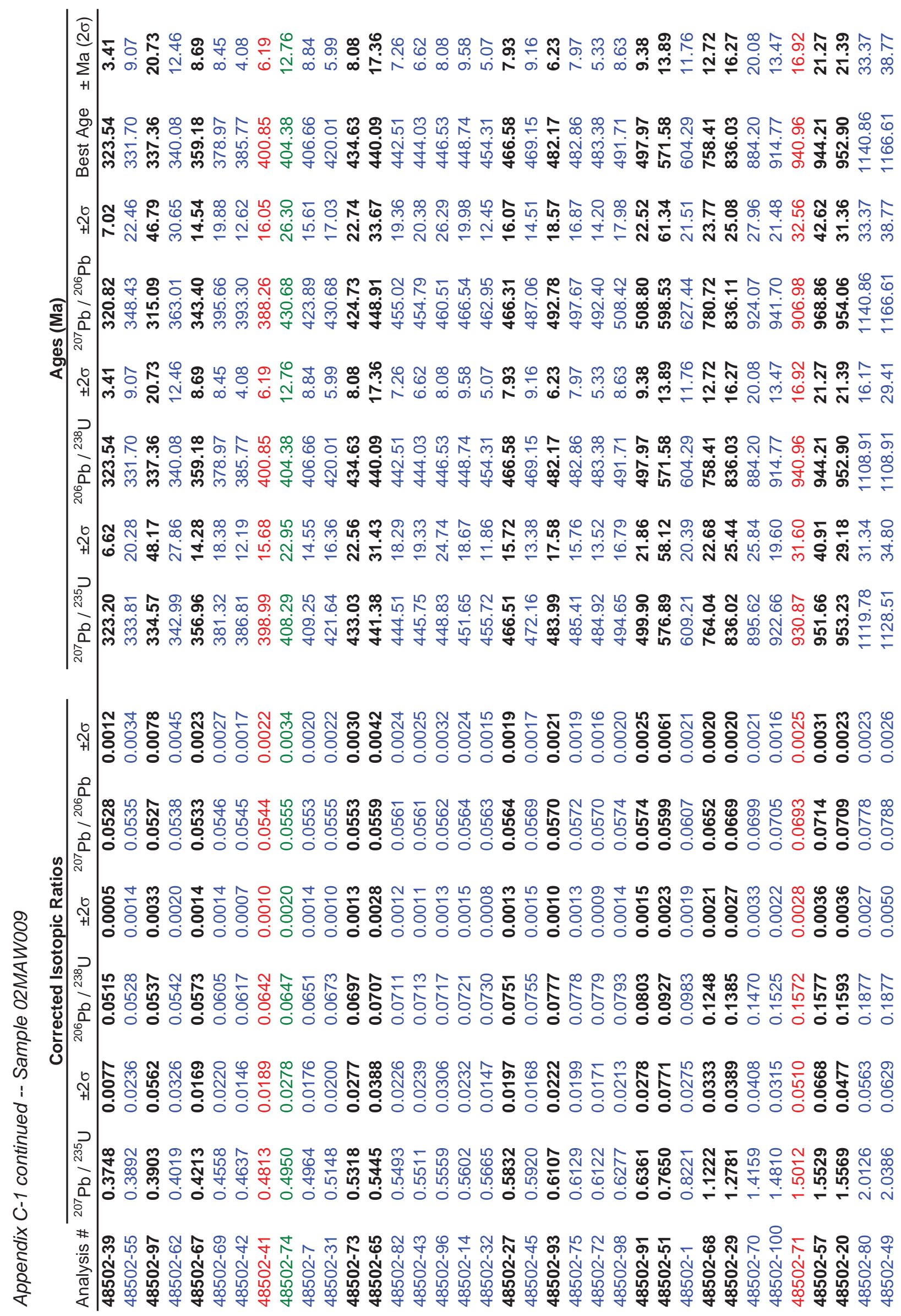




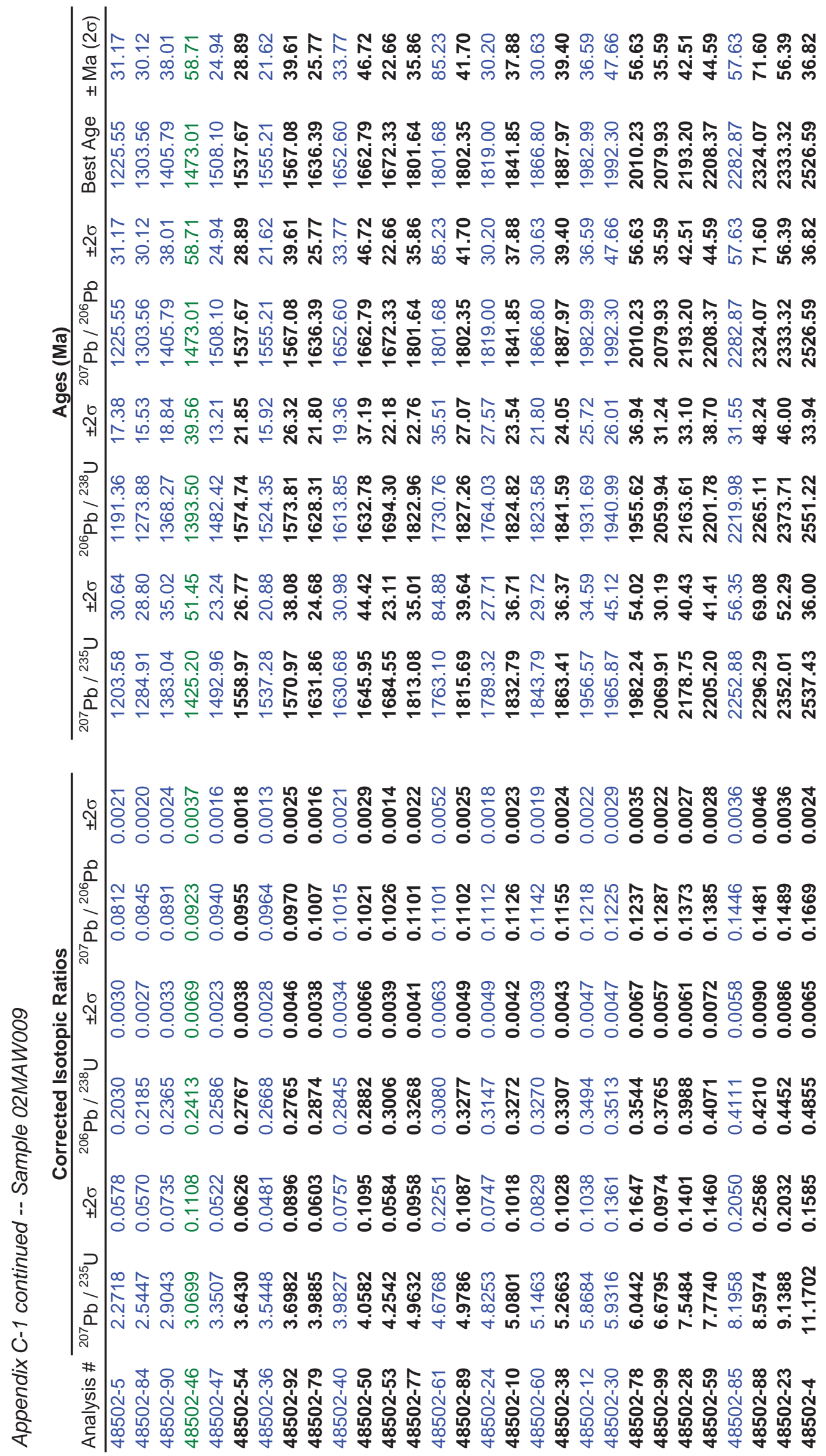




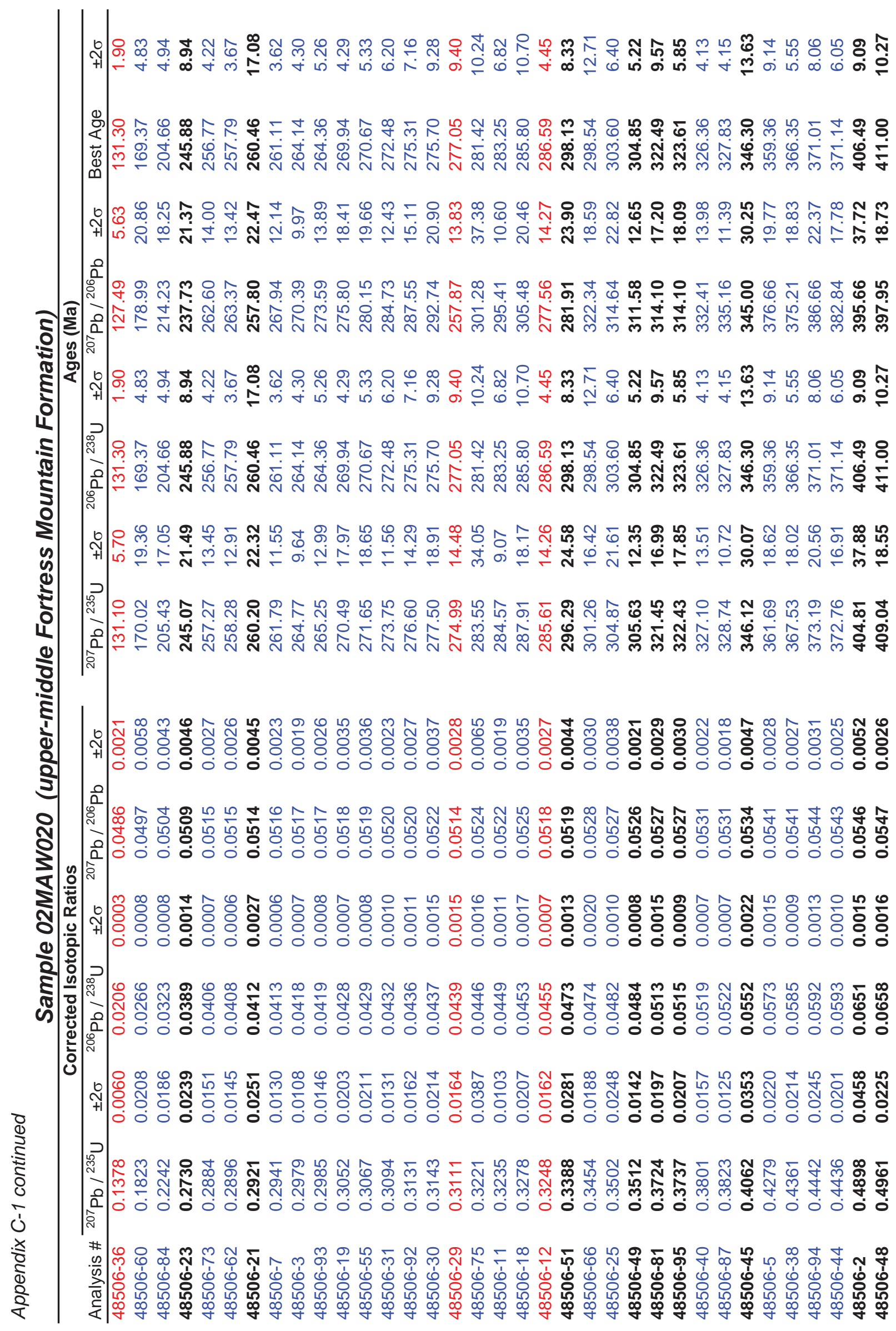


点

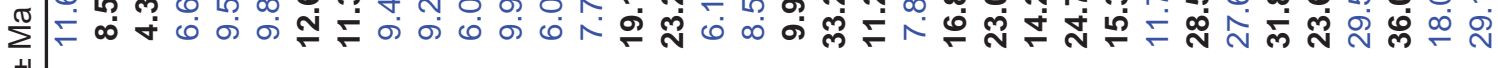

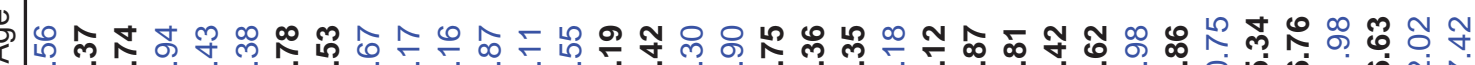

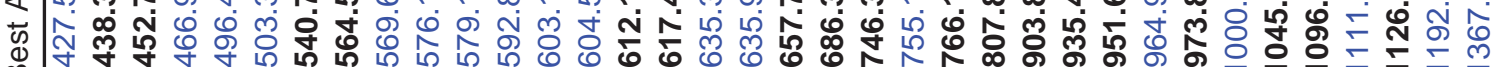

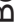

๒

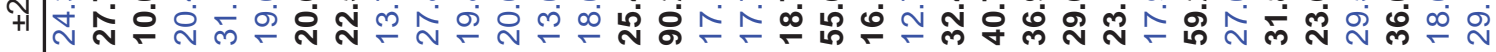
응

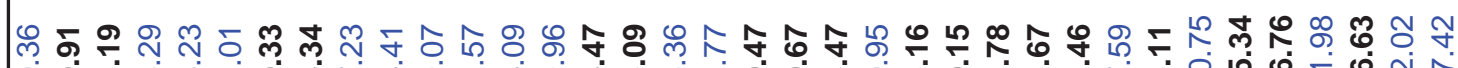
(ำ

운 +1

兽

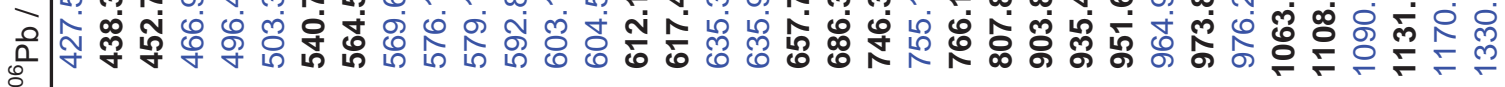
$\stackrel{\circ}{\circ}$

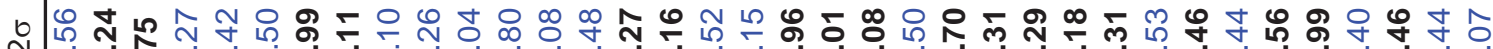
+1 N $\supset$

赵

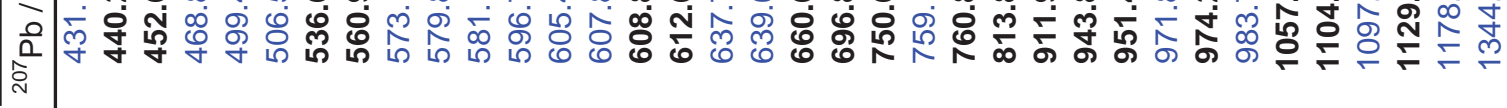

ט +1 $\circ$

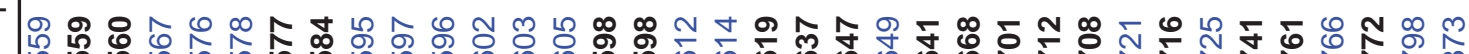

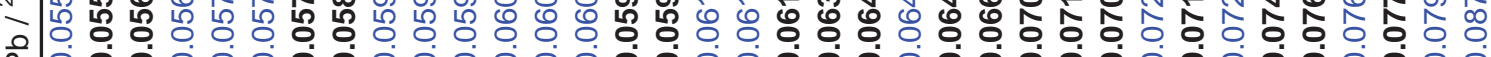
ยิก

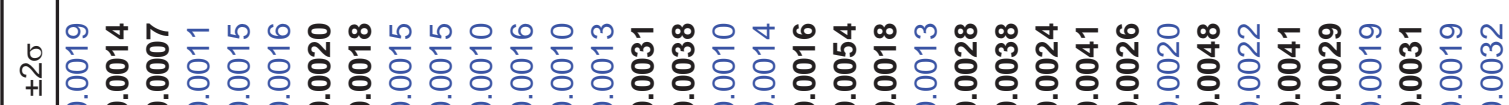
ᄀ)

○ オ

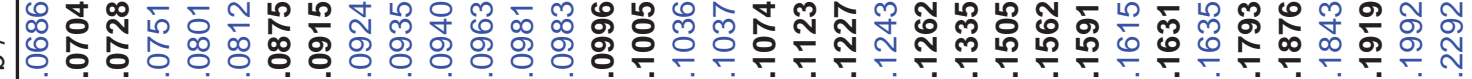
屯े

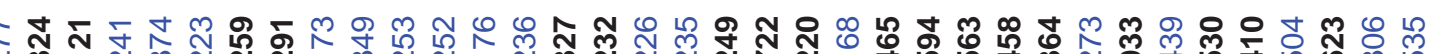

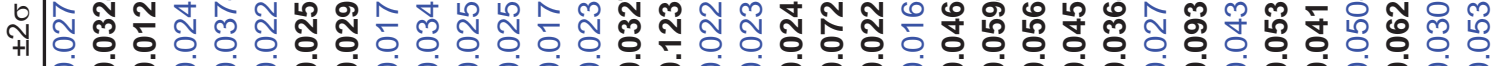

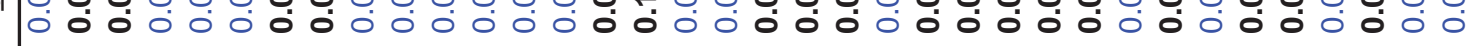
ح)

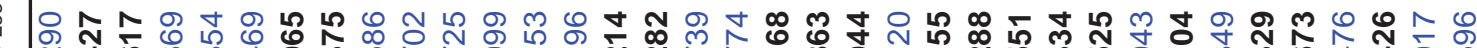

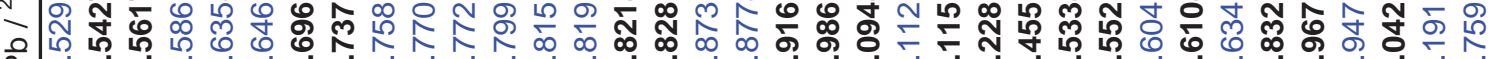

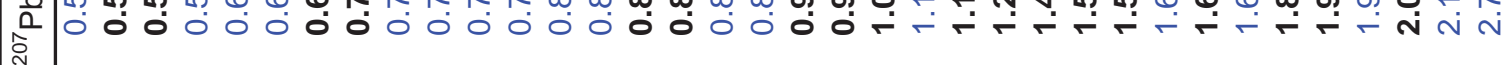
ì

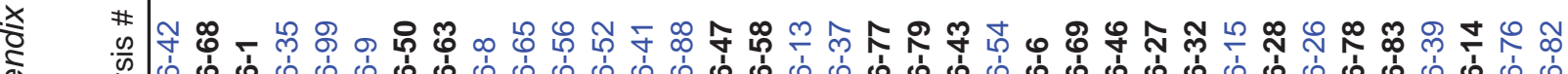

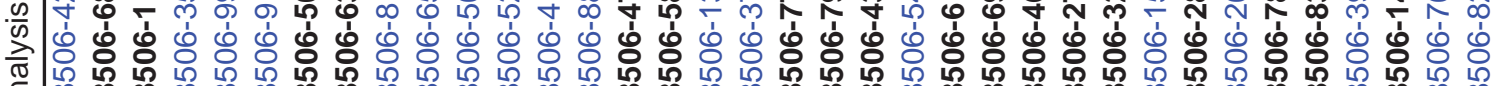
定| 


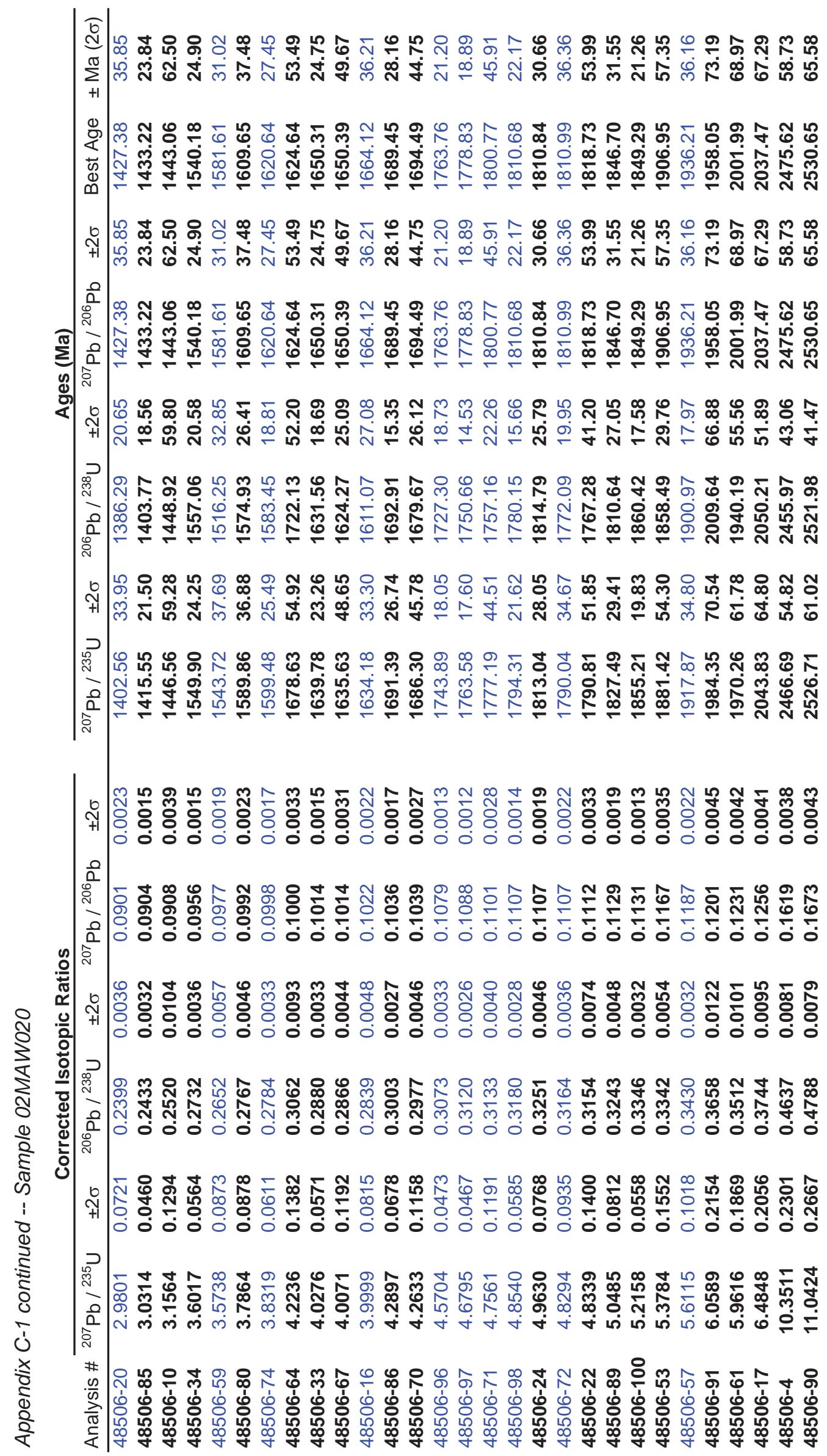




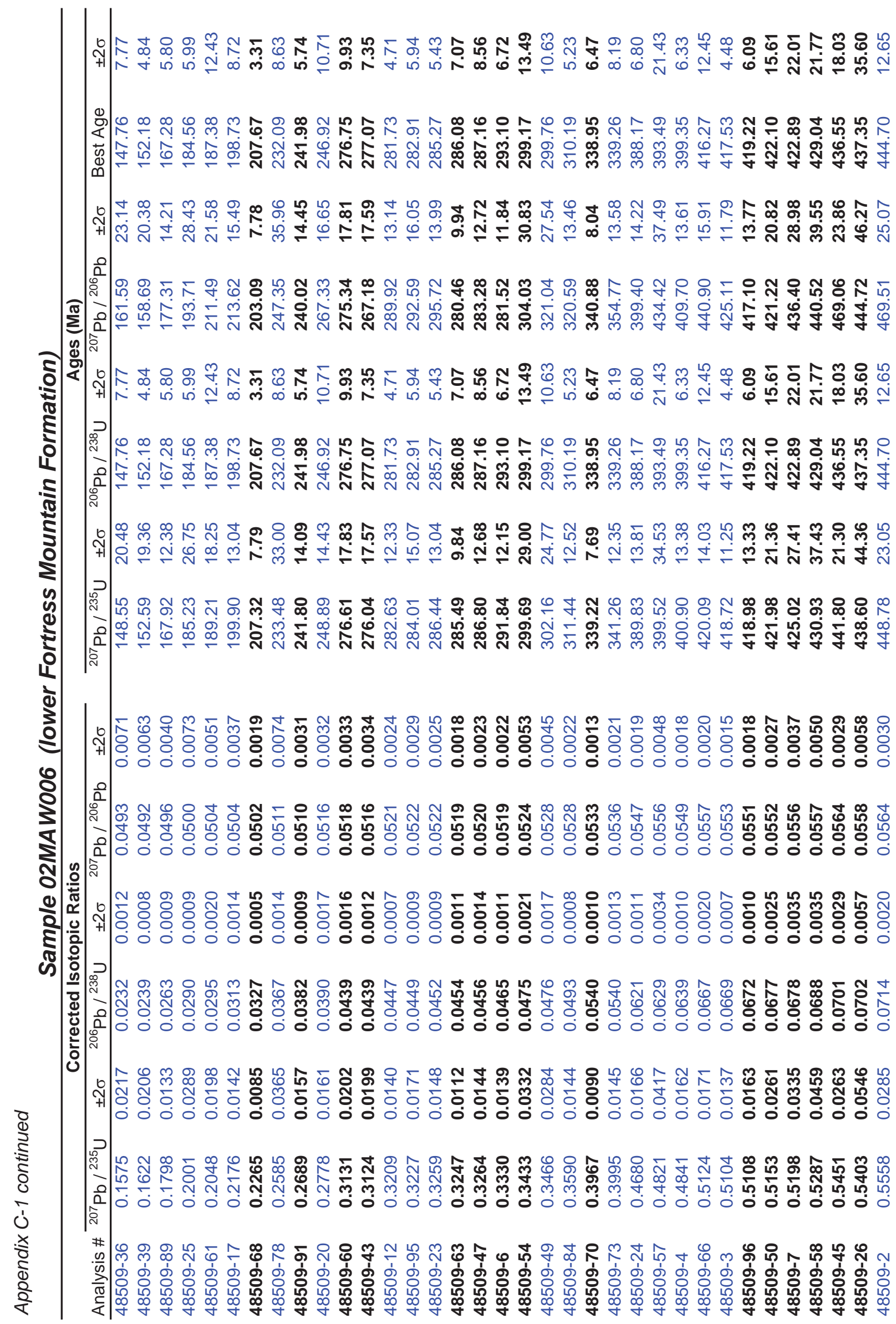




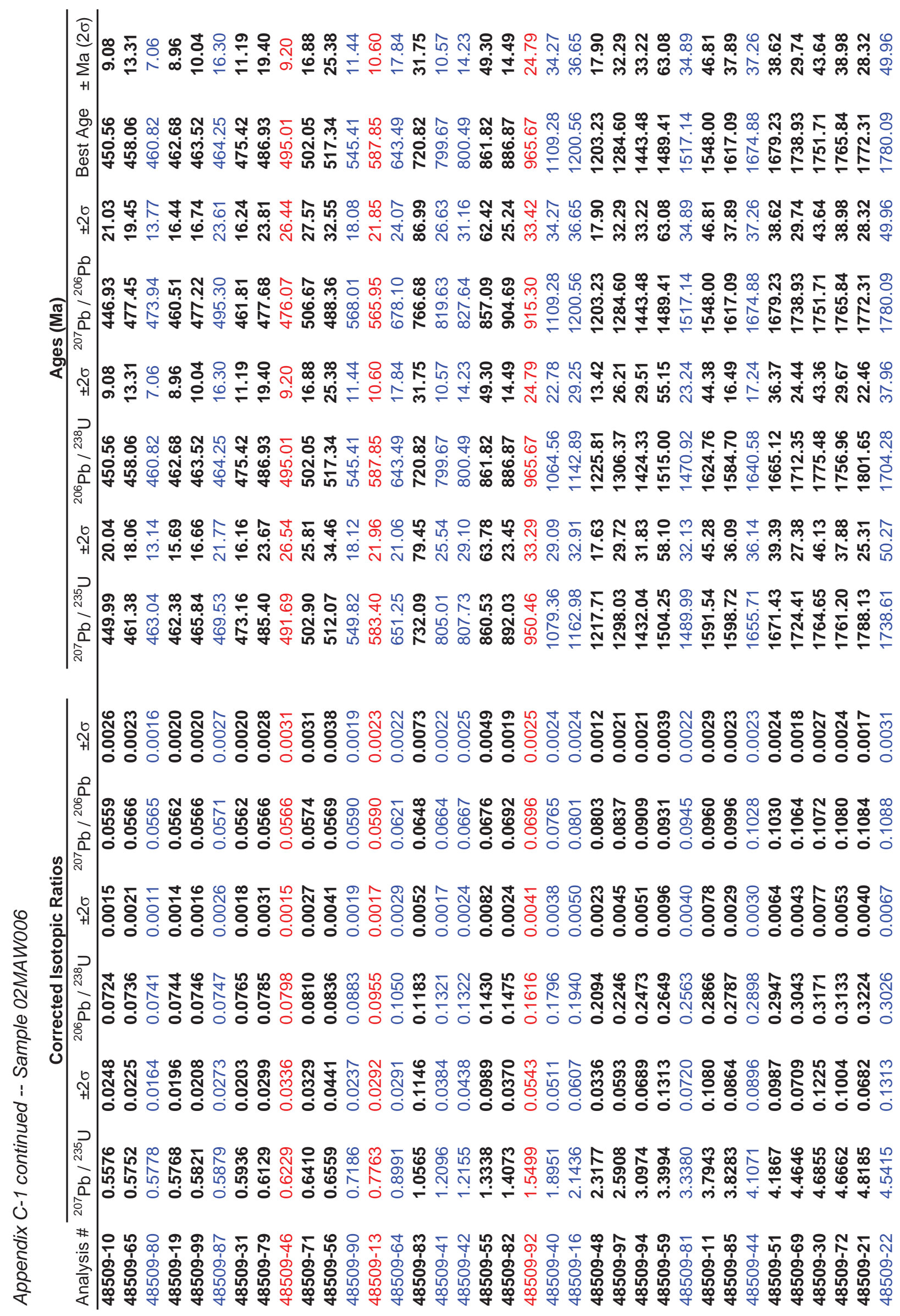




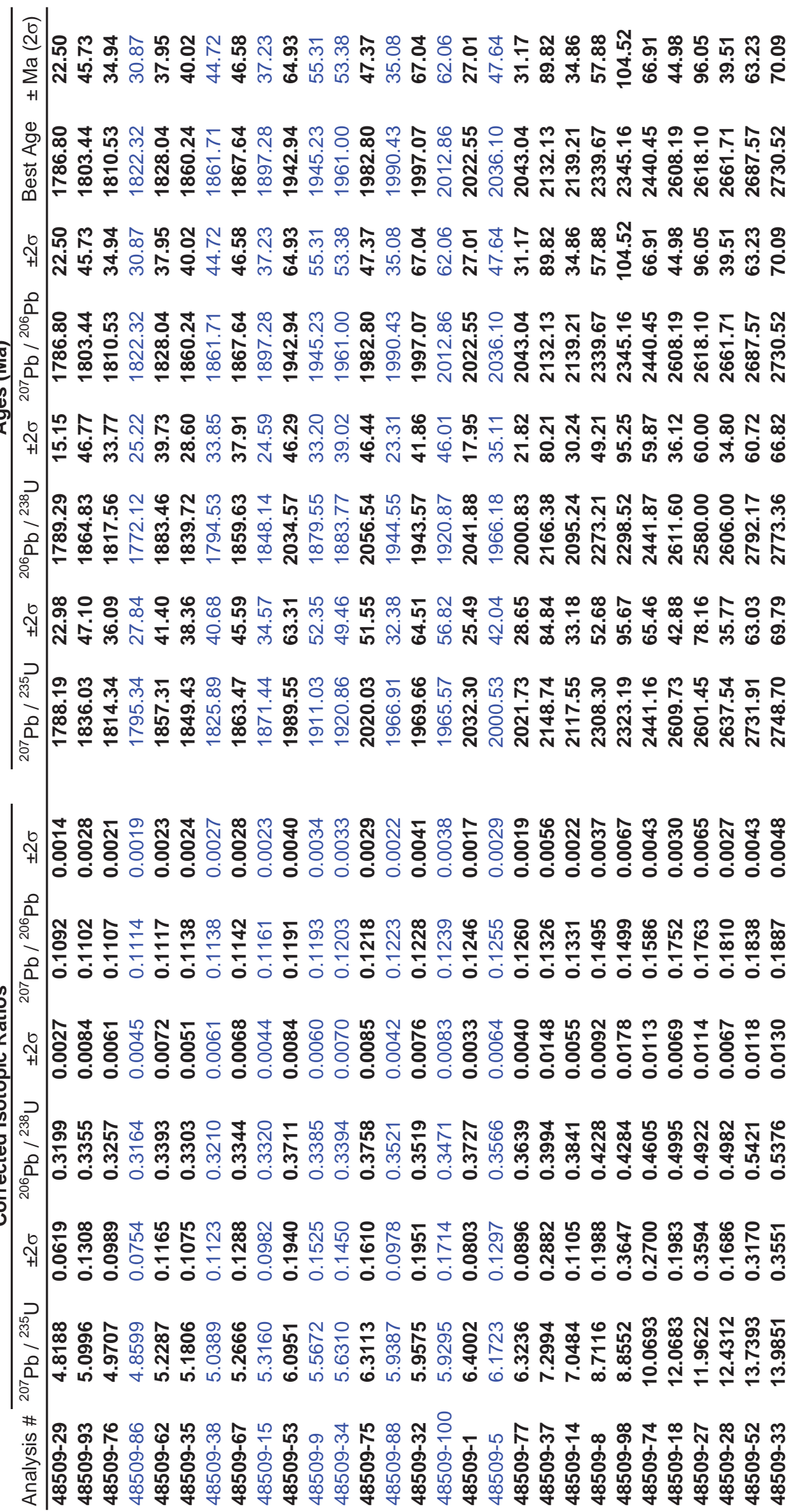

